\title{
Cities, sustainability and health
}

\section{Creating healthy, just and eco-sensitive cities}

\section{GUEST EDITORS}

\author{
Anthony G. Capon ${ }^{\mathrm{A}, \mathrm{B}, \mathrm{C}}$ and Jane M. Dixon ${ }^{\mathrm{B}}$ \\ A Australian Health Policy Institute, The University of Sydney. \\ ${ }^{\mathrm{B}}$ National Centre for Epidemiology and Population Health, The Australian National University. \\ ${ }^{\mathrm{C}}$ Corresponding author. Email: acapon@med.usyd.edu.au
}

This issue introduces the first of two special issues of the NSW Public Health Bulletin that examine health and cities. This issue introduces the topic and identifies the challenges for public health workers and their counterparts in urban management (urban, transport and social planners, environmental engineers and auditors, sustainability officers and others) and the land development and infrastructure sectors of industry. The second issue will focus on ways to move forward by describing urban planning and design approaches to enhance population health.

\section{Cities: the dominant human habitat}

Cities can be great places in which to live. Currently, $90 \%$ of the Australian population chooses to live in urban settlements. People are attracted to cities for many reasons, including the availability of employment, education, social and cultural opportunities, and access to shops, food outlets, health care and other services.

The United Nations has estimated that during 2007 the human species will become a predominantly urban species; for the first time in human history more than half of all people will live in cities. ${ }^{1}$ Consequently, the governance of cities is increasingly important for human futures. Those responsible should manage our cities in the interests of both human health and the health of the environment.

\section{Cities, sustainability and health}

The way people live in cities affects their health by influencing levels of physical activity, food choices, safety, social connection and participation, and exposure to pollutants. These influences are determinants of common, contemporary health problems such as obesity, diabetes, heart disease, some cancers, depression, injury and asthma. The way people live in cities also affects the health of the environment through loss of biodiversity, changes to ecosystems, carbon dioxide emissions and the production of other pollutants. These environmental changes, in turn, have feedback impacts on human health.

Within cities there is inequity in access to infrastructure and other resources. ${ }^{2}$ This applies to transport (mass transit, in particular), healthy food outlets, other shops, parks, libraries and health and community services, and creates barriers to good health and environmental outcomes in both large cities and smaller urban settlements.

These are the challenges we will explore in two special issues of the Bulletin. While health workers have a discourse on 'urban health', ${ }^{3}$ urbanists have a discourse on 'sustainable cities'. ${ }^{4}$ Here we seek an integrated perspective on cities, sustainability and health, and present emerging ecological approaches and systems thinking.

\section{Paradigm shift}

Concerns about urban sustainability and population health are not new. For example, the Australian National University established the Hong Kong Human Ecology Program in the early 1970s. This was supported by the United Nations Educational, Cultural and Scientific Organization and was the first attempt to understand the ecology of a city and its human population in a holistic and integrated way. ${ }^{5}$ This program demonstrated that the actions necessary to protect the biosphere correspond substantially with those required to maintain and improve the quality of human life experience.

In the 1980s, the World Health Organization established the 
Healthy Cities initiative. ${ }^{6}$ The goal of Healthy Cities projects is the integration of health in decision-making in cities, through partnerships between public and private sectors and community participation. Several Australian cities have become Healthy Cities, including Illawarra and Blacktown in New South Wales and Noarlunga in South Australia.

In recent years, there has been a paradigm shift in the way public health workers think about health and the urban environment. ${ }^{7}$ This shift reflects an improved understanding of the importance of environmental determinants of health and has been enabled by new approaches to research. ${ }^{8}$ During 2004, the Year of the Built Environment in Australia, there were many activities and events designed to raise awareness about urban environmental issues. The NSW Government Architect initiated a healthy environments project and published a booklet on the topic. ${ }^{9}$ The booklet contains 11 essays about health and the environment by researchers and practitioners in the field.

The Standing Committee on Environment and Heritage in the Australian House of Representatives reported on the sustainability of cities in 2005. The Committee is now inquiring into a charter and commission for sustainability in Australia. The response to these inquiries has the potential to shape the future of Australian cities. It is important that population health is a central consideration in the response as cities cannot be sustainable unless they are healthy places in which to live. ${ }^{10}$

\section{Fenner Conference on the Environment}

The Australian Academy of Science hosted a Fenner Conference on the topic Urbanism, Environment and Health in Canberra in May 2006. The conference examined ways of living in cities and the consequences for our health and for the environment. It was delivered through a partnership between those interested in population health and urban environments, and included perspectives from research, policy, the private sector and the community. More information, including abstracts and audio recordings, is available on the conference website. ${ }^{11}$

Following the Fenner Conference, The Sydney Morning Herald published a series of articles on Sick Cities in August 2006, including case studies reviewed by Dr Chris Rissel, director of health promotion with Sydney South West Area Health Service. The Herald maintains a multimedia website on this topic, with the articles and additional audio and video material. ${ }^{12}$

The papers in this issue have been developed from presentations at the 2006 Fenner Conference. McMichael provides a concise history of cities and public health from the industrial era to the present, with a focus on Australia and England. He highlights major urban health penalties and responses to them. He emphasises the importance of ensuring human health is a central consideration in the sustainability discourse, for both policy and practice.

Howe argues for a renewed focus on urban policy in Australia. She is persuasive about the need for effective governance to enable the three levels of government in Australia to work with the community and the private sector to develop healthy and sustainable cities. Kearns, Beaty and Barnett from CSIRO Sustainable Ecosystems present an extended urban metabolism model as a framework for linking urban resource inputs to the spatial patterns and organisational processes of urban consumption. They identify important relationships between urban metabolism and human health.

Capon and Blakely propose a checklist for healthy and sustainable communities. The checklist identifies attributes of urban environments that affect the health of residents and the health of the environment. It is intended to stimulate debate and could be developed as a tool for government and industry.

Box $1^{13-17}$ contains a glossary of the terms used in these two special issues that may be unfamiliar to the usual readership of the Bulletin.

\section{Meeting the challenge}

Boyden has proposed a conceptual framework to represent the biophysical and cultural components of systems. ${ }^{18}$ This framework can help us to understand the urban system and the impact of changes to variables within the system. The framework has utility as a tool for the planning and evaluation of interventions.

Health impact assessment is another tool for applying public health analysis to the built environment. ${ }^{8}$ The Centre for Health Equity Training, Research and Evaluation at University of New South Wales is currently funded by NSW Health to promote the use of equity-focused health impact assessment as a policy, planning and evaluation tool. ${ }^{19}$ An example of one project under this initiative is the health impact assessment of the Sydney Metropolitan Strategy. A brief report of this follows this editorial.

To achieve healthy, equitable and sustainable cities, it will be necessary to strengthen professional relationships between urbanists and public health workers. Partnerships can be fostered through collaborative projects (both research and intervention), joint workforce development and advocacy. There is also a need for further innovation in scientific method. The science supporting sustainability is an emerging science that seeks to understand the interactions between nature and society. ${ }^{20}$ Only through such work, across and between traditional disciplines, will we develop the knowledge and approaches necessary to address the challenge of health and cities. 


\section{Box 1. Glossary}

\begin{tabular}{|c|c|}
\hline Biodiversity ${ }^{13}$ & $\begin{array}{l}\text { The variability among living organisms from all sources, including terrestrial, marine and other aquatic } \\
\text { ecosystems and the ecological complexes of which they are part. Biodiversity includes diversity within } \\
\text { species, between species and between ecosystems. }\end{array}$ \\
\hline Bioregion $^{14}$ & $\begin{array}{l}\text { A region with borders that are naturally defined by topographical systems (such as mountains, rivers } \\
\text { and oceans) and ecological systems (such as deserts, rainforests and tundra). }\end{array}$ \\
\hline Biosphere $^{15}$ & $\begin{array}{l}\text { The part of the Earth's environment in which living organisms are found and with which they interact to } \\
\text { produce a steady-state system. }\end{array}$ \\
\hline Ecological footprint ${ }^{13}$ & $\begin{array}{l}\text { An index of the area of productive land and aquatic ecosystems required to produce the resources used } \\
\text { and to assimilate the wastes produced by a defined population at a specified material standard of } \\
\text { living, wherever on Earth that land may be located. }\end{array}$ \\
\hline Ecology ${ }^{15}$ & $\begin{array}{l}\text { The scientific study of the inter-relationships among organisms and between organisms, and between } \\
\text { them and all aspects, living and non-living, of their environment. }\end{array}$ \\
\hline Ecosphere $^{15}$ & $\begin{array}{l}\text { Similar to biosphere. The term ecosphere is used to emphasise the interconnection of the living and } \\
\text { non-living components. }\end{array}$ \\
\hline Ecosystem ${ }^{13}$ & $\begin{array}{l}\text { A dynamic complex of plant, animal and microorganism communities, and their non-living } \\
\text { environment, interacting as a functional unit. }\end{array}$ \\
\hline Health ${ }^{16}$ & $\begin{array}{l}\text { A state of complete physical, mental and social well-being and not merely the absence of disease or } \\
\text { infirmity. }\end{array}$ \\
\hline Sustainability ${ }^{13}$ & $\begin{array}{l}\text { A characteristic or state whereby the needs of the present and local population can be met without } \\
\text { compromising the ability of future generations or populations in other locations to meet their needs. }\end{array}$ \\
\hline Urban systems ${ }^{13}$ & $\begin{array}{l}\text { Built environments with a high human population density. Operationally defined as human settlements } \\
\text { with a minimum population density commonly in the range of } 400 \text { to } 1000 \text { persons per square } \\
\text { kilometre, minimum size of typically between } 1000 \text { and } 5000 \text { people, maximum agricultural } \\
\text { employment usually in the vicinity of } 50-75 \% \text {. }\end{array}$ \\
\hline Urbanisation $^{13}$ & An increase in the proportion of a population living in urban areas. \\
\hline Urbanism $^{17}$ & Urban way of life. \\
\hline
\end{tabular}

More than 15 years ago, Ashton argued for a new approach to environmental health, a shift from sanitarian to ecologist. ${ }^{21}$ NSW public health workers should now embrace this challenge. It is through everyday activities that, as citizens, we all experience the highs and lows of city life. For this reason, we should also encourage vigorous debate in the wider community about this important topic.

\section{Acknowledgements}

The authors acknowledge financial support from the Australian Academy of Science for the 2006 Fenner Conference on the Environment. Additional financial support for the Conference was received from The Australian National University, Sydney West Area Health Service, Commonwealth Scientific and Industrial Research Organisation, the Australian Government's Department of Environment and Heritage, Australian Ethical Investment Ltd and Public Health Association of Australia Inc.

\section{References}

1. United Nations, Department of Economic and Social Affairs, Population Division. World urbanization prospects: the 2003 revision. New York: United Nations, 2004. Available at http://www.unpopulation.org [Verified 10 May 2007].

2. Stilwell F, Jordan K. Who gets what? Analysing economic inequality in Australia. Cambridge: Cambridge University Press, 2007.
3. Galea S, Vlahov D. Handbook of urban health: populations, methods and practice. New York: Springer, 2005.

4. Newman P, Kenworthy J. Sustainability and cities: overcoming automobile dependence. Washington DC: Island Press, 1999.

5. Boyden S, Millar S, Newcombe K, O'Neill B. The ecology of a city and its people. Canberra: Australian National University Press, 1981.

6. Ashton J, Grey P, Barnard K. Healthy cities - WHO's new public health initiative. Health Promot 1986; 1: 319-24. doi:10.1093/heapro/1.3.319

7. O'Donnell MP. Health promoting community design. Am $J$ Health Promot 2003; 18: iv-v.

8. Frumkin H, Frank L, Jackson R. Urban sprawl and public health: designing, planning and building for healthy communities. Washington DC: Island Press. 2004.

9. Johnson C, editor. Healthy environments. Sydney: Government Architect's Publications, 2004.

10. Capon T. Cities fit to live in. About the House (Australian House of Representatives Magazine) 2003; 19: 20-23

11. Urbanism, environment and health. Fenner Conference 2006; 2006 May 25-26; Canberra: National Centre for Epidemiology and Population Health, The Australian National University, 2006. Available at http://nceph.anu.edu.au/Fenner2006/ index.htm [Verified 10 May 2007]. 
12. Sick cities. Fast life, slow death. Sydney: The Sydney Morning Herald. Available at http://www.smh.com.au/multimedia/ sickcities/index.html [Verified 10 May 2007].

13. Millennium Ecosystem Assessment. Ecosystems and human well-being. Our human planet: summary for decision-makers. Washington DC: Island Press, 2005.

14. McGraw-Hill. Dictionary of bioscience. 2nd edn. New York: McGraw-Hill, 2003.

15. Allaby M, editor. A dictionary of ecology. 3rd edn. Oxford: Oxford University Press, 2005.

16. World Health Organization. Basic documents. 45th edn. Geneva: WHO, 2005.
17. The Australian concise Oxford Dictionary. 4th edn. Melbourne: Oxford University Press, 2004.

18. Boyden S. The biology of civilisation. Sydney: University of New South Wales Press, 2004.

19. Harris E, Sainsbury P, Staff M. Health impact assessment in New South Wales. N S W Public Health Bull 2005; 16: 105-6.

20. McMichael AJ, Butler CD, Folke C. New visions for addressing sustainability. In: Kennedy D, editor. Science Magazine's State of the Planet 2006-2007. Washington DC: Island Press, 2006. p. 161-166.

21. Ashton J. Sanitarian becomes ecologist: the new environmental health. BMJ 1991; 302: 189-90.

\section{Report on the health impact assessment of the Sydney Metropolitan Strategy in greater western Sydney}

In 2006, the NSW Department of Planning finalised its Sydney Metropolitan Strategy, a strategic framework for managing the city over the next 25 years. The Strategy's intent is to enable the NSW Government and the market to confidently respond to economic growth and housing and infrastructure need, to strengthen and secure Sydney's economic competitiveness, and to make Sydney a better place to live. ${ }^{1}$

For more than 5 years, regional government and non-government organisations in western Sydney have been advocating for change in urban development across greater western Sydney to improve the health of residents. These organisations - which include the Western Sydney Regional Organisation of Councils (which represents 11 local councils), the area health services, and the Centre for Health Equity Training, Research and Evaluation - are currently collaborating on a health impact assessment (HIA) of the Sydney Metropolitan Strategy within this region.

The premise of the HIA was that the success of policies for the management of a city should be measured in terms of the environment and the health of its residents, rather than measures of transport movements and economic development.

The objectives of the HIA were to:

- raise awareness of health and well-being as important criteria for urban development policy;

- gather and analyse the best available data on urban development decisions and health and well-being relevant to Sydney;

- make recommendations about the strengths and weaknesses of the Sydney Metropolitan Strategy which can also inform future planning instruments in NSW; and

- facilitate an on-going dialogue between development stakeholders about health and well-being issues.

To achieve these goals it was essential to engage decision-makers in urban development. This was achieved through the formation of a reference group of 40 stakeholders drawn from industry, government, academia and community. The reference group, supported by consultants, identified dimensions of the urban environment (including urban form, transport and economy) and determinants of health (including physical activity, food access and social capital) for Sydney. The approach aligned with the World Health Organization's 'The Solid Facts: Social Determinants of Health.'2 The reference group has been crucial in identifying specific issues for Sydney's future development. These include location of employment, the need for timely delivery of transport and social infrastructure, access to shops and services at a local level, and the value of preserving agricultural lands.

The HIA was funded by NSW Health. The final report will be available in mid-2007. Further information is available from Colin Berryman, Western Sydney Regional Organisation of Councils, Blacktown.

References

1. NSW Government's Metropolitan Strategy. Sydney: Department of Planning, 2004. Available at http://www.metrostrategy.nsw.gov.au/dev/uploads/paper/introduction/index.html. Accessed 23 April 2007.

2. Wilkinson R, Marmot M, editors. Social determinants of health: the solid facts. 2nd Edn. Denmark: World Health Organization, 2003. 


\section{Will considerations of environmental sustainability revitalise the policy links between the urban environment and health?}

\author{
Anthony J. McMichael \\ National Centre for Epidemiology and Population Health, \\ The Australian National University. \\ Email:tony.mcmichael@anu.edu.au
}

\begin{abstract}
This paper explores when and how considerations of population health have influenced the creation, planning and management of cities. Cities - now the dominant human habitat - must be planned and managed sustainably in a world that is manifestly experiencing increasing environmental and social strains. Early industrialisation entailed crowding, squalor and industrial environmental blight; the two great associated public health hazards were infectious diseases and air pollution. These hazards have been largely controlled in rich countries. Today's main urban health hazards are obesity (with its life-shortening health consequences) and the huge contribution of cities to climate change with the resultant risks to population health. These and other health issues in urban environments need to be understood and addressed at the community or population level. This is an ecological challenge, crucial to attaining real sustainability.
\end{abstract}

Before the modern Scientific Age, with limited understanding of disease causation, health promotion was not a prominent objective in the development and administration of cities. Plato's utopian ideal city invoked politics, ethics and social relations - but not health. Half a millennium later, imperial Rome struggled to accommodate, feed and service its burgeoning population. The city coped with its massive sewage disposal needs via the engineering works of the cloacae, which emptied into the River Tiber.

Over recent millennia, cities have evolved from rural, river-port or seaside villages and towns, usually with little planning. This process continues today in much of the developing world, where urban growth and form is predominantly driven by land markets, 'western' precedents (roads, cars, shopping malls) and assorted entrepreneurs. The local accumulation of wastes and pollution of air and waterways is regarded as incidental 'collateral'.

Cities have arisen late in the evolutionary-biological experience of the human species. As artificial environments, they confer both benefits and risks to human wellbeing and health. (The squalor and life-shortening risks of urban-industrial life in early 19th century England stimulated the emergence of epidemiological research and the formal agencies of public health.) To what extent then has the betterment of population health been an explicit consideration in the creation, planning and management of cities? This question has growing relevance today. The world's cities - now the dominant human habitat - must be planned and managed sustainably in a world experiencing increasing environmental and social strains. Sustainable urban environments will:

(i) support healthy living now and into the future (e.g. by providing: equitable access to good food; physical activity; social cohesion; minimised microbial transmission; and aesthetic and cultural fulfilment) and

(ii) minimise the ecological 'footprint' of cities, so as to sustain the world's health-supporting capacity for future generations.

To foster this ecological perspective and render urban policy and planning processes more attuned to the biological, psychological and social needs of humans, we may benefit from exploring recent history. First, though, it is important to clarify what is meant by 'the ecological perspective'.

\section{Cities and health: thinking ecologically}

Within popular culture, we usually think of health and disease in personalised, individual-level terms. However, the relationship between urban environments, city living and health needs to be viewed on a larger canvas; it needs to be understood within a 'human ecology' framework. The urban environment exerts various systemic influences that affect the rates of disease in the urban population at large. While individual-level factors (behaviours, genes, happenstance) influence which particular individuals get sick, the population's overall rate of disease reflects properties of the shared physical, social and cultural environment, that is, the community's overall way of living. 
Consider the contemporary problem of the rise of obesity. The conjoined processes of industrialisation, urbanisation, modernisation and the rise of consumer culture have influenced both of the discretionary components of the energy balance equation: (i) food energy intake and (ii) physical activity. While being overweight is not confined to urban populations, cities have been the engine-room of social and technological change that has lead to an 'obesogenic' modern environment. From this perspective the problem is primarily one of a systemic change in our way of living, rather than a consequence of defective individual behaviour.

A systems-based approach also enables us to view the various aspects and impacts of the urban transport system within a more integrated framework. This approach highlights the great diversity of direct and indirect health impacts from our transport-related behaviours (Fig. 1).

This approach invites questions about how other systemic influences of the urban environment on the public's health (sometimes referred to published reports as 'urban health penalties') have changed over recent time.

\section{The changing profile of urban health penalties}

In the early stages of industrialisation, 200 years ago, the crowding, squalor, poverty and industrial environmental blight led to two great urban health penalties. Various infectious diseases became rife and were prime killers; meanwhile, in factory towns and cities the air became black with smoke. By the mid-20th century these two great health hazards of early urban-industrial life had largely been controlled in rich countries.

The narrative continues today. Two of the greatest healthendangering correlates of urban environments and living are, first, overweight and obesity (discussed above) and, second, the increasing contribution of cities to greenhouse gas emissions and the attendant risks to safety, health and survival.

An important new dimension of these two modern health problems is that both extend well beyond the boundaries of cities and affect the population at large. For example, energy use in cities and the resultant greenhouse gas emissions have consequences, via climate change, for humans everywhere. The resultant health risks include the affect of heatwaves, especially in cities; exacerbation of local air pollution; mudslides endangering shanty towns; intensified extreme weather events; and heightened transmission of temperature-sensitive infections.

Time trends in these major urban health penalties are summarised, albeit notionally, in Fig. 2, as are the main social policy responses. Changes over time in theories of the determinants of disease are also shown.

Before next considering in more detail how these systemic urban-environmental public health problems have arisen and been responded to historically, two other modern urban health penalties should be noted.

First, infectious diseases pose an unexpectedly large, resurgent health threat in the modern urban setting. While the 'classical' water- and food-borne infections due to poor hygiene have receded, respiratory infections retain the potential for rapid spread in population-dense settings. This is evident from the urban-based outbreak and spread of Severe Acute Respiratory Syndrome (SARS) in 2003. Other aspects of urban culture, including sexual networking and illicit drug use, potentiate the spread of various infections, including HIV/AIDS and hepatitis C.

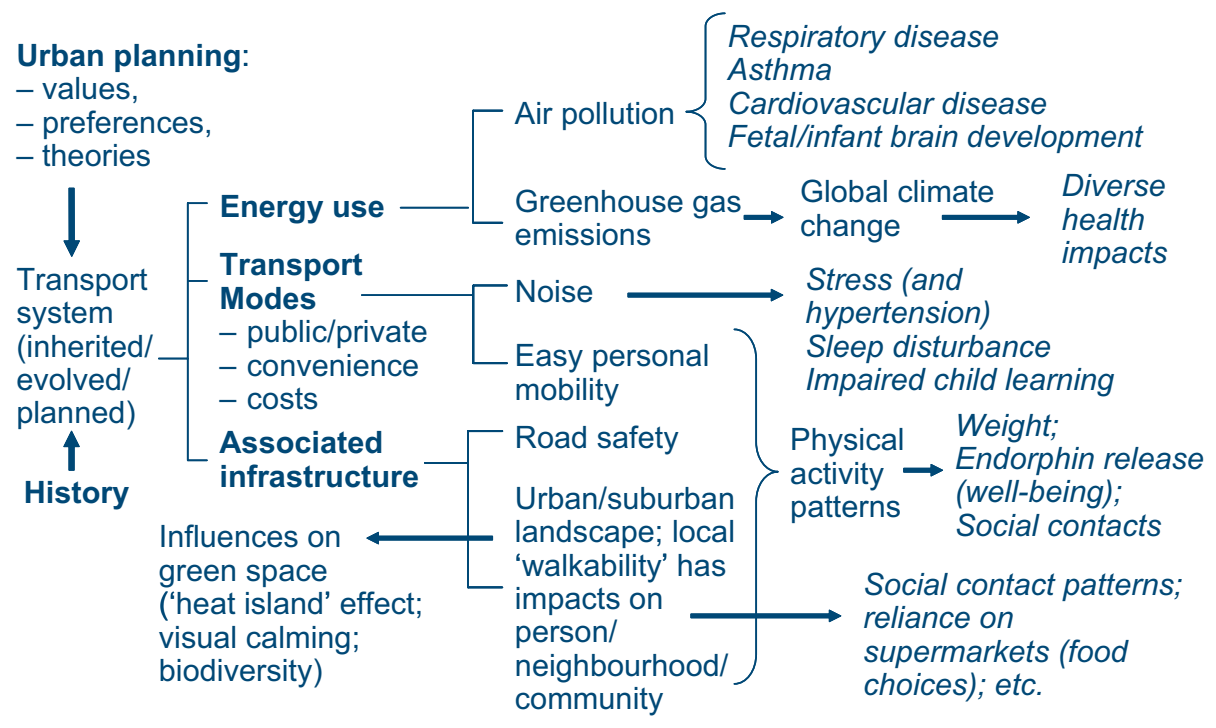

Fig. 1. An ecological perspective of the origins and the social and health impacts of urban transport systems and related human behaviours. 
Second, there appears to be an increase (albeit still inadequately researched) in the prevalence of mental health disorders in urban populations, most notably depression. The connection is not straightforward. But cities are the mainspring of the aspirational consumer culture and its associated 'emptiness' of spirit - a culture reinforced in the urban setting via sophisticated and pervasive advertising and marketing and where shopping (on credit and by car) is easy. There is evidence that this urban consumer culture fosters dissatisfaction, alienation and mental health problems. ${ }^{1}$

\section{The history of urban health problems and policy responses in England and Australia over the past 200 years}

We come then to the question of whether and how considerations of risks to health have guided urban planning and management in modern times. The recent history of the fluctuating role of health considerations in city planning begins most observably in early 19th century Europe.

\section{Infectious diseases: miasmas, germs and people}

The need for domestic hygiene and public sanitation was increasingly recognised by European governments from the mid-19th century. Sanitary reforms and new infrastructure yielded health gains. Motives were mixed: personal protection, enhanced economic productivity and environmental amenity all loomed large.

The record is well documented in England. Sanitary reform was framed largely in relation to the longstanding 'miasma' theory of disease. The foul air-borne emanations ('miasmas') that spread diseases were attributed to dank squalor and filth. Edwin Chadwick and his celebrated
Report on the Sanitary Conditions of the Labouring Population of Great Britain (1842) looms large in any such account. ${ }^{2}$ Chadwick believed that local miasmas caused the 'endemic and contagious diseases' rife within the poorer crowded sections of London. The Public Health Act of 1848 flowed from Chadwick's report, giving local boards of health power to install and improve sewage and sanitation.

While this legislative initiative apparently reflected recognition that good health must be a prime goal of urban planning, Chadwick's motivation was essentially utilitarian. Successful industrialisation required a healthy workforce and much of the weakness and poverty of the 'labouring population' was due to chronic poor health from a squalid miasma-ridden environment.

In Australia in the latter 19th century, urban epidemics of diarrhoeal and respiratory diseases persisted. The stench of Melbourne's inner suburbs was dire. In 1876, after two bad years of epidemics of measles and assorted streptococcal infections, the Melbourne Board of Health reported: ${ }^{3}$

'The contagium which causes epidemics is the offspring of insanitary habits, and is nurtured and spread by the impure air of unventilated houses. ... In a great many parts, the houses are not only damp, but impregnated with poisonous gas from pent-up sewage.'

Miasma theory was evidently then central to public health thinking in Melbourne, and helped propel the introduction of sewering. This almost certainly contributed to the

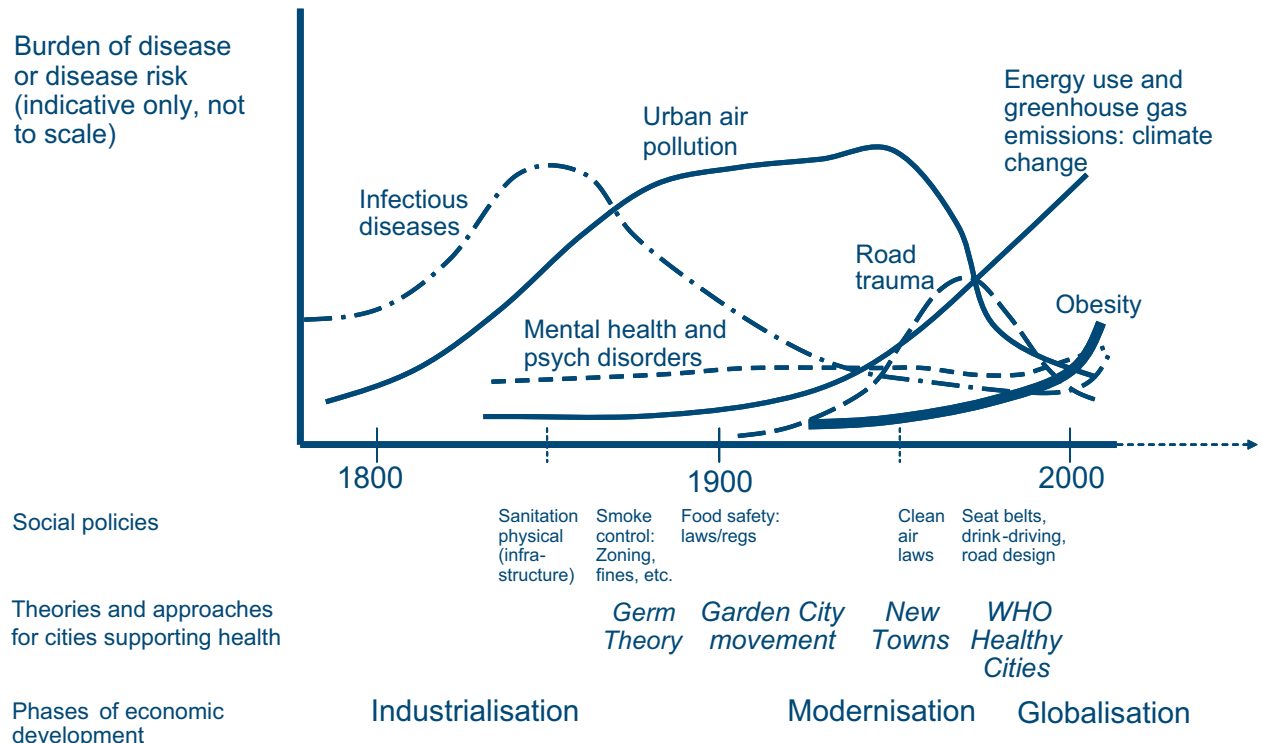

Fig. 2. The rise and fall of major urban health penalties in developed countries over the past two centuries. (The main remedial responses and influential emergent theories of cities, wellbeing and health are shown at the bottom.) 
marked fall in infant mortality that began around 1890, halving rates of death in Victoria overall by around $1920 .{ }^{4}$

Meanwhile, in late 19th century Europe the ideas of Pasteur and Koch were replacing miasmatic thinking with the specific concepts of the Germ Theory. This nurtured a paradigm shift in public health thinking, with new focus on specific disease agents and the possibilities for prevention at individual and family levels.

\section{'Dark satanic mills': coal combustion, particulates and health}

During those early infection-blighted decades another great public health blight was the escalating concentration of black smoke in urban-industrial air. Coal-burning in England dates from at least 1000 years ago. During the High Middle Ages and Renaissance centuries, royal edicts were issued to curb the burning of coal, especially in London. Queen Elizabeth I complained that coal smoke caused her grievous annoyance.

The dense smoke pollution in mid-19th century industrialising Britain posed a different type of challenge from miasmas and sewage. The latter was an infrastructural issue, requiring government intervention. However, factory smoke was politically more difficult because of its direct association with the desired economic expansion. ${ }^{5}$ Official awareness of the health risks from air pollution emerged in the 1840s. The Smoke Acts of the 1850s were targeted specifically at London, empowering the police to enforce provisions against factories, furnaces, public baths and steam-boats on the Thames.

It took another 100 years before serious attention was paid to controlling rampant urban air pollution with its oftendramatic health impacts. That turnabout in public thinking and policy finally happened following the notorious London Smog of 1952. The long-overdue Clean Air Act was passed in the late 1950s. Similar legislation was enacted during the following two decades in most other industrialised countries.

\section{The story continues}

In England, the Health of Towns Association had formed in the 1840 s, allied with the emerging sanitary reforms. In 1875, Benjamin Ward Richardson, an English physician-sanitarian and social reformer, proposed Hygeia: medium-density cities of 100000 persons, green spaces, a good transport system, and clean air and water. In the 1890s, Ebenezer Howard proposed building health-supporting self-sufficient 'garden cities' for populations of approximately 32000 . He prescribed a specific layout, with concentric layering of commercial, green-space, market-garden and residential areas. ${ }^{6}$

The garden city idea had influences in the USA and in
Germany. In Australia, the design of Canberra, by the American architect Walter Burley Griffin during 1910-11, drew heavily on Howard's ideas. The Garden City concept was revived again in England after World War II; the New Towns Act (1946) promoted Howard's egalitarian and health-promoting vision.

This 'build better to live better' rhetoric, however, can nurture an uncritical assumption that the right physical layout will, of itself, promote health. Reality is more complex; social environments, population mix, economic currents, history, good planning and inspired local leadership are all important. This integrated perspective was adopted in the 1970s-80s as global population growth rates soared and urbanisation accelerated. This coincided with the rise of community-based health promotion strategies, as in WHO's international 'Healthy Cities' program, which provided frameworks and guidance for the development of healthy urban environments. ${ }^{7,8}$

Australia has recently had a federal parliamentary enquiry into 'Sustainable Cities 2025'. ' The real index of sustainability is the quality of human experience and its durability across generations. The widely invoked 'triple bottom-line accounting' (comprising indices of economic activity, environment and social conditions) actually refers to intermediate markers - markers of the conditions that determine human experience. Therefore, population health must now be mainstreamed, as a key criterion of sustainability, into the planning and management of our cities.

\section{Conclusion}

We humans are social animals, seeking comfort, security, variety and opportunity. Settled living in villages, towns and cities attracts us. Worldwide, as cities proliferate, we have become a predominantly urban species. We must now learn to shape and manage the urban environment to accord with the needs of human biology and of the ecosphere. ${ }^{10}$

In the early 19th century, health problems were conceptualised and addressed at the population-community level. The Germ Theory redirected attention towards specific individual-level factors. Much of modern epidemiological research has continued in that individualist vein, focusing on personalised behaviours and circumstances that account for why some persons have heart attacks or cancer and some do not. Today, we are necessarily recognising, again, the fundamental role of environmental systems and processes as ecological determinants of population health.

Our growing awareness that health risks to whole populations arise from changes in ways of living, in cultural priorities and from the ever-widening impacts of humans on environmental assets and systems (including the climate system) underscores the urgent need to understand that 
population health is the central criterion of sustainability. Our prime, anthropocentric reason for seeking social stability, a congenial and safe urban environment, and the maintenance of nature's life-support systems is to ensure the protection and improvement of human wellbeing, health and survival.

\section{References}

1. Eckersley R. Is modern Western culture a health hazard? Int $J$ Epidemiol 2006; 35: 252-8. doi:10.1093/ije/dyi235

2. Finer SE. The life and times of Sir Edwin Chadwick. London: Methuen and Co., 1952.

3. McCalman J. 'All just melted with heat': mothers, babies and 'hot winds' in colonial Melbourne. In: Sherratt T, Griffiths T, Robin L, editors, A change in the weather. Canberra: National Museum of Australia Press, 2005, p. 114.

4. Cumpston J. Health and disease in Australia, Lewis MJ, editor. Canberra: AGPS, 1989, p. 108.
5. Kessel A. Air and public health. Cambridge: Cambridge University Press, 2005, p. 56.

6. Howard E. To-morrow: a peaceful path to real reform, 1898. Republished London: Routledge, 2003.

7. Awofeso N. The Healthy Cities approach - reflections on a framework for improving global health. Bull World Health Organ 2003; 81(3): 222-3.

8. Stephens C. Healthy cities or unhealthy islands? The health and social implications of urban inequality. Environ Urban 1996; 8: 9-30. doi:10.1177/095624789600800211

9. House of Representatives Standing Committee on Environment and Heritage. Sustainable cities 2025. Canberra: The Parliament of the Commonwealth of Australia, 2005.

10. McMichael AJ. Chapter 9. In: Human frontiers, environments and disease: past patterns, uncertain futures. Cambridge: Cambridge University Press, 2001.

\section{Developing a national approach to building healthy and sustainable cities}

\section{Renate T. Howe}

School of History and Heritage Society, Deakin University. Email:renate.howe@deakin.edu.au

\begin{abstract}
Effective strategies to build a national approach to the integration of health and urban planning at all levels of government is essential if the health problems of urban Australians, such as obesity and respiratory illnesses, are to improve. This paper examines some policies and initiatives that could facilitate intergovernment cooperation on health and sustainability within the constraints of Australia's federal government system. These include recommendations for an Australian Sustainability Commission and Charter of Sustainability, evaluations of the Better Cities Program of the 1990s, and current proposals for improving urban governance to enable the implementation of a healthy and sustainable cities agenda.
\end{abstract}

Health is not generally perceived as an urban planning issue although 'many of today's health problems are embedded physically and culturally in the ways that we build and inhabit our cities. ${ }^{11}$ In Australia's federal system of government, urban planning requires coordination between three levels of government (national, state and local); $;^{2,3}$ however, there has been limited effort over the past decade to promote a coordinated national response to urban issues. This paper examines some emerging governance strategies to facilitate the better integration of health and urban planning in Australian cities.

\section{Australian House of Representatives inquiry into sustainable cities}

A recent development has been the appointment, with bipartisan support, of a House of Representatives Standing Committee to inquire into sustainable cities. In 2005, the inquiry produced the Sustainable Cities Report, ${ }^{4}$ recommending: the establishment of an Australian Sustainability Commission to monitor progress in cities; the appointment of a Sustainability Commissioner; and the development of a Charter of Sustainability. The possibility of identifying and including health objectives in a charter is an encouraging starting point, although there has been little evidence of high-level political support from the Australian Government for implementation of the Charter's recommendations.

Submissions received by the committee encouraged them to revisit the Better Cities Program (1991-96) as a model for intergovernmental cooperation in the planning and 
management of urban development. Using an area strategy approach, the Better Cities Program encouraged innovative project management techniques and objectives for improving the quality of life..$^{5-7}$ A National Cities Program, similar to the Better Cities Program, was suggested by some submissions. Although the Sustainable Cities Report concluded that there was a clear case for leadership in the development of national urban policy, a major weakness of its recommendations was the lack of financial incentives for the development of a coordinated intergovernment approach through the proposed Australian Sustainability Commission.

\section{Facilitating intergovernment cooperation in urban issues}

Intergovernment cooperation is under consideration by the Local Government and Planning Ministers' Council in response to a proposal for a National Program on Sustainable Communities that was prepared in 2004 by major stakeholders (the Planning Institute of Australia, Property Council of Australia, the Planning Officials Group and the Royal Australian Institute of Architects). The National Action Plan based on the proposal comprises: seven propositions related to a shared vision; a national plan of action; urban action plans; a sustainable communities commission; a national sustainable communities fund; performance indicators; and sustainable regulation.

At the request of the Council of Australian Governments, a Development Assessment Forum was established in 1998, including all levels of government and national stakeholder bodies, to develop a way for the different state planning systems to achieve agreed outcomes. So far these outcomes have focused on achieving efficiency in the regulation of land use development and have not addressed broader social or health issues. ${ }^{8}$ However, the Development Assessment Forum indicates the possibilities of initiating cooperative approaches between different levels of government and stakeholders that foster more long-term strategic planning, enabling the integration of health objectives.

\section{Lessons from the Better Cities Program}

An effective national approach for urban health and planning requires more than these cautious attempts at coordination and falls short of the combination of national leadership, shared funding and an area strategy focus which was used effectively in the Better Cities Program. Evaluations of the Better Cities Program identified that the area strategy approach facilitated a focus on placebased needs. Area strategies, which encouraged social interaction, especially in the planning of public spaces, were found to have contributed to well-being and security. ${ }^{9}$ The Better Cities Program also demonstrated the importance of focusing on outcomes to overcome fragmentation in governance:
It showed that if we could overcome the political divisions between departments, between structures we could then overcome the kind of segmented way we think, to think more laterally. If we could look more at the outcomes we wanted to achieve than the inputs the governments find so difficult to drum up, then we would be able to do much more creative, worthwhile things. ${ }^{10}$

\section{Lessons from the United Kingdom}

It is hard to see a commitment in Australia to the scale of intervention needed for a national program for sustainable and healthy communities. Certainly there is nothing equivalent to the United Kingdom Government's Sustainable Communities Plan of 2003, an impressive and comprehensive plan backed by $£ 38$ million of commitments addressing housing, infrastructure, regional growth, homelessness, environmental improvement, urban renewal, planning system reform and related economic, social welfare, health and educational changes. ${ }^{11}$

\section{Transport and housing policy}

Essential underpinning for healthy and sustainable cities is transport and housing policy. The Department of Transport and Regional Services program, Aus Link, was a promising model of national infrastructure provision but focused on road transport not urban public transport. At the state level, infrastructure planning and development is usually undertaken under public-private partnerships, which are driven by efficiency objectives. There has been little consideration of health and sustainability implications in larger transport projects, which usually by-pass ordinary land use planning policies and procedures. ${ }^{12}$ In relation to housing policy, the Australian Government, states and territories cannot agree on the development of a national housing strategy. This has contributed to ad hoc coastal residential development and poorly designed and sited metropolitan greenfields developments. More dense development in the inner and middle suburbs of our larger cities has been poorly integrated with health objectives.

National leadership and commitment is essential for a sustainable and healthy cities agenda. An assessment by Lyndsay Nielson (former secretary of the Department of Sustainability and Environment in Victoria) of the implementation of the Melbourne 2030 strategy has noted that most states have developed sophisticated urban strategies in the absence of 'any articulated national framework of policy'. ${ }^{13}$ While from a national perspective there is consistency between the state policies, these need a federal urban policy framework and funding to be effective. For example, the more dense activity centres integral to Melbourne 2030 need federal support for the necessary public transport infrastructure to be successful. 


\section{Improving urban governance}

A national planning approach also depends on wellresourced institutions to run our cities. The Planning Institute of Australia is urging the establishment of Metropolitan or Sustainability Commissions within cities to achieve coordination and policy focus. ${ }^{14}$ Marcus Spiller, past president of the Institute, believes that state and local government cooperation is too difficult to achieve in urban planning, citing obstructive and parochial local governments as the reason. ${ }^{15}$ The Institute is lobbying for Metropolitan Commissions that would be democratically elected and representative of the city as a whole rather than local municipalities, to restore 'long-termism' to metropolitan strategic planning and overcome the present fragmentation of decision-making. Spiller argues that although Metropolitan Commissions introduce a new tier of government they are the type of metropolitan institutions needed to implement a sustainability agenda.

More feasible are Development Corporations and Redevelopment Authorities that have been used for specific projects, for example at Ultimo-Pyrmont and Redfern in Sydney, the East Perth Redevelopment Authority (all Better Cities projects) and the Docklands Redevelopment Authority in Melbourne. A model for key transit cities and activity centres under Melbourne 2030 has been introduced in the outer suburban City of Dandenong, where the Minister for Planning has been deemed the planning authority responsible for social and economic development, with the Dandenong Council and the Dandenong Development Board acting in an advisory capacity. Although the role of local government within these models has been contentious, the authorities have the potential to insert health objectives into local and regional planning.

While governance changes are essential to achieve sustainable cities there are a range of other initiatives that can integrate health outcomes in planning decision-making. Courses in planning are recognising the need to train a new generation of planners with a stronger understanding of the connections between health and sustainability. A small but important step towards mainstreaming health issues into the planning system has been the appointment of a part-time health planner at Planning Institute of Australia's Victorian branch. The planner is financed by Vic Health and The Cancer Council Victoria and the planner's brief is to integrate the enabling of healthy, active life styles into planning decision making.

\section{Conclusion}

If Australia is to have sustainable cities, "more innovative and visionary thinking among leaders of the key organizations and associations - public and private - that are significant players in metropolitan development' is required. ${ }^{16}$ While little progress has been made over the past decade, developments such as the Sustainable Cities Report, the possibilities presented by the initiatives of the Council of Australian Government, and the focus on improving urban governance are encouraging. Recent political awareness of the urgent need for sustainable development and of endemic environmental urban health problems could mobilise the political support needed for health issues to be part of moves towards sustainable urban planning.

\section{References}

1. McMichael T. Opening remarks and welcome. In: Urbanism, Environment and Health, Fenner Conference; 2006 May 25-26; Canberra, Australia.

2. Fletcher $\mathrm{C}$, Walsh $\mathrm{C}$, editors. The impact of federalism on metropolitan strategies in Australia. Canberra: Federalism Research Centre, Australian National University, 1992.

3. Wright B. Expectations of a better world: planning Australian communities. Canberra: Royal Australian Planning Institute, 2001.

4. House of Representatives Environment and Heritage Committee. Sustainable cities report, August 2005. Available at http://www.aph.gov.au/house/committee/environ/ cities/report.htm [Verified 3 April 2007].

5. Howe B. Reflecting on better cities. Australian Planner 2001; 38(1): 38-44.

6. Australian National Audit Office. Building better cities. Canberra: October 1996.

7. Victoria Auditor General. Building better cities - a joint government approach to urban development, Special Report No 45; Melbourne: 1996.

8. Australian Government Department of Transport and Regional Services. A leading practice model for development assessment. Canberra: Commonwealth of Australia, 2006. Available at http://www.daf.gov.au [Verified 3 April 2007].

9. Gerner RP. Urban design and the better cities program: the influence of urban design on the outcomes of the program [thesis]. Sydney: University of Sydney; 2002. p. 70-293.

10. Howe B. The role of the national government in Building Better Cities, 1991-1996. In: Dawkins J and Searle G, editors. Australia's better cities, University of Technology papers on planning, No 9. Sydney: University of Sydney, December 1996; p. 22.

11. Office of the Deputy Prime Minister. Sustainable communities plan. London: HMSO, February 2003.

12. Stilwell F, Jordan K. In the public interest: an investigation of the pitfalls of PPPs. Arena Magazine 2004; 72: 9-12.

13. Neilson L. Managing urban change: the need for diversity and choice in housing and urban development. 12th Annual Oswald Barnett Oration, Melbourne, October 2005; pp. 15-18.

14. Planning Institute of Australia. Liveable communities: how the Commonwealth can foster sustainable cities and regions. Canberra: February 2004.

15. Spiller M. Rebuilding our metropolitan planning institutions. Australian Planner 2005; 42(3): 14-5.

16. Newton P. Urban Australia 2001. Australian Planner 2002; 39(1): 37-45. 


\section{A social-ecological perspective on health in urban environments}

\section{Allen Kearns ${ }^{\mathrm{A}, \mathrm{B}}$, Matthew Beaty ${ }^{\mathrm{A}}$ and Guy Barnett ${ }^{\mathrm{A}}$}

A Urban Systems Program, CSIRO Sustainable Ecosystems.

BCorresponding author: Allen.Kearns@csiro.au

\begin{abstract}
Human health in our cities is an expression of complex social and environmental interactions not previously faced in our long evolutionary history. In this paper, we present a social-ecological perspective on the complex nature of emerging public health problems in cities and identify some of the research questions emerging from this new view of the city. We argue that an integrative urban science agenda is needed not only to inform urban policy, planning and design, but also to alert people to the consequences of and trade-offs around their choices and behaviours.
\end{abstract}

Our cities are dynamic places where increasing numbers of people are choosing to live their lives. The present built form of the city closely reflects: (i) the geography and ecological history of particular places; (ii) the historic interactions between founding populations of people; (iii) how they used the natural resources they found; and (iv) how they decided to build infrastructure in their new environment. ${ }^{1-3}$ In any city you can see how urban settlement patterns have been shaped by cumulative decisions that at first influence and then determine the trajectories of urban, industrial and infrastructure developments. Global drivers of change, such as climate variability, globalising markets, terrorism, rapid urbanisation, increasing human populations, rising per capita consumption and risk of pandemic disease also influence the development of cities. ${ }^{4,5}$ These factors represent some of the main challenges for the future health of people in cities and their urban bioregions, the ecological systems on which cities depend. ${ }^{6}$

\section{Urban environments and health}

Urban environments are rapidly changing, and people as individuals and as part of organisations are constantly adapting to new opportunities and threats. Not surprisingly, along with the benefits that urban life brings to many, there are a range of old and new health risks that are now affecting increasing numbers of individuals and their communities. In the 20 th century, public health, civil engineering and environmental science were successful in reducing the incidence of health problems through point source treatment of clean water, the removal and treatment of wastewater and garbage, and the regulation of industrial wastes, effluents and emissions. ${ }^{7,8}$ The rising tide of $21 \mathrm{st}$ century public health problems, such as obesity, cardiovascular disease and depression, are different to past problems that could be directly attributed to infectious agents, toxic chemicals, poor industrial design and a lack of effective environmental management.

The new diseases of urban living arise more from the complex way we now live, eat, travel, build, play and work in urban environments, rather than from any single agency. Our health is now an expression of a complex web of interactions that have not been previously faced during human evolution and these interactions are more subtle and indirect in their action. They include factors such as: (i) the time we spend commuting to work; (ii) how we individually respond to the abundance of energy-rich foods and drinks brought to us through the industrial food chain; (iii) the availability or otherwise of opportunities to be physically active; and (iv) the time we have for self-reflection and family. While these factors act on individuals, all have become highly socially organised and mediated through changing cultural aspirations and norms, urban systems of governance, infrastructure, modes of transport, and the supply and demand of urban goods and services such as food, water, energy and transport.

\section{Cities as social-ecological systems}

A social-ecological perspective focuses on cities as 'urban ecosystems', as distinct from the traditional 'ecology in the city' approach, which addresses the distribution, abundance and management requirements of biodiversity in the city. ${ }^{9}$ The urban ecosystem approach views the city as a distinct type of ecosystem characterised by the linkages between social and ecological processes and asks questions about the spatial, systems and social context of urban people and the extent of their interdependence on their urban bioregion. For example, from where do urban people derive their water, energy and food; where do people spend most of their time; how far do they travel to work, school and recreational outlets; and what social-ecological conditions contribute to their cultural identity, sense of place and health? The urban ecosystem approach also identifies our interdependence on natural 
systems in remote catchments and urban environments to provide biodiversity and ecosystem services (i.e. those unpriced ecological processes provided by natural systems that clean our water and air, pollinate our plants, recycle our nutrients and enhance our urban quality of life and our health through the rejuvenating aspects of recreation). The urban ecosystem approach is a human-based ecology that recognises the critical aspects of urban systems of governance in sustaining urban quality of life. In particular, urban people have a strong social and institutional dependence on reliable flows of goods and services such as water, energy, food, construction materials, transport, health services, information and capital to sustain health.

As an example, the Extended Urban Metabolism Model ${ }^{10}$ (Fig. 1) provides a useful social-ecological framework for linking the industrial production of these urban resource inputs (food, materials, water, energy and information) to the spatial patterns and organisational processes that characterise urban consumption. Resources, both physical and social, are transformed, or 'metabolised', and distributed through urban governance systems and infrastructure networks with emergent consequences for people and urban environments. Research can be directed at developing a better understanding of the effect of these processes on the health of people in cities. For example, what factors increase the rates of industrial production of high-energy, low-cost foods and what are the consequences for targeted populations of urban consumers? Or, what are the social and health costs of inadequate transport infrastructure and consequent loss of personal and family time from long commutes to work and sedentary lifestyles?

\section{Research questions generated from a social-ecological perspective}

A social-ecological perspective could enable research into:

- The spatial and temporal dynamics of social and environmental determinants of human health in urban systems. ${ }^{11}$ Who gets sick and where do they live?

What are the relative contributions of social versus environmental factors? What types of interventions are available and appropriate?

- Measures of health in different urban forms. ${ }^{12,13}$ What contribution does urban pattern and social-ecological processes in urban environments make to the functionality of urban habitats? Can we identify the characteristics of dysfunctional and functional urban landscapes and incorporate this knowledge into better urban planning, design, construction and management?

- Urban resilience to shocks and disturbances caused by natural and human disasters. ${ }^{14,15}$ Can we identify aspects of our social, natural and built environment that make us vulnerable? Can we build resilience into our infrastructure and the way we organise ourselves as communities?

\section{- Maintenance of ecosystem services and food} production in urban environments. ${ }^{16}$ In both cities and the rapidly urbanising rural lands that surround them, how important is it to conserve natural systems and sustain agricultural lands for healthy local food production? What role could this play in preserving our long-term environmental and food security?

- Social capital for coping with and adapting to change in urbanising landscapes. ${ }^{17}$ How prepared are existing rural and urban communities to adapt to the pace and scale of changes caused by rapid urbanisation? What are the health consequences of the inability of local people to adapt to changing urban transport patterns, social processes and globalisation?

- Measures of urban quality of life that address the effects of surplus consumption. ${ }^{18}$ What educational changes, and access to information and knowledge, are necessary to raise awareness about the individual health consequences of surplus consumption, particularly of food, but also of energy, water and construction materials? What policy platforms are needed to create an enabling environment for better urban health?

This social-ecological perspective ${ }^{19}$ on the complex nature of emerging public health problems presents a

\begin{tabular}{|c|c|c|}
\hline $\begin{array}{l}\text { Urban resource } \\
\text { inputs }\end{array}$ & $\begin{array}{l}\text { Urban systems and } \\
\text { processes }\end{array}$ & Outcomes \\
\hline \multirow[t]{3}{*}{$\begin{array}{l}\text { People, Information, Food } \\
\text { Energy, Water, Materials, } \\
\text { Transport, Housing, } \\
\text { Land, Biodiversity }\end{array}$} & \multirow{3}{*}{$\begin{array}{l}\text { Urban governance } \\
\text { Industrial processes } \\
\text { Distribution of goods } \\
\text { Provision of services } \\
\text { Urban design and } \\
\text { development }\end{array}$} & $\begin{array}{l}\text { Liveability } \\
\text { Health } \\
\text { Environmental health } \\
\text { Culture and heritage }\end{array}$ \\
\hline & & $\begin{array}{l}\text { Urban environmental } \\
\text { quality } \\
\text { Air, Water, Noise }\end{array}$ \\
\hline & & Wastes and emissions \\
\hline
\end{tabular}

Fig. 1. The Extended Urban Metabolism Model adapted from Newton et al. ${ }^{10}$

This simplified version of the model provides a useful checklist of inputs, processes and outcomes that need to be considered in a social-ecological framework. 
major new challenge for how urban society generates the understanding required to find an integrated set of solutions that address these complex problems. Partial solutions generated by traditionally distinct professional disciplines are unlikely to match the spatial scale and pace of these emerging health problems in urban environments. However, more integrated solutions will require health professionals, epidemiologists, engineers, environmental scientists, urban planners, designers and managers, policy specialists, economists and social scientists to come to grips with working together in new ways. ${ }^{20}$ For example, an integrated approach to urban science would require interdisciplinary knowledge from many areas to address the complex social-ecological interactions that are contributing to the rise of overweight and obese people in increasingly dysfunctional urban environments. Researchers working in partnership with people in urban practice, policy and communities will be an essential part of a research agenda for sustainable development that would address these complex health problems. Changes will also be needed in how we plan, design, construct, monitor and evaluate old and new urban developments to identify what interventions enhance the prospects for people to improve their health as part of their day-to-day interactions in rapidly urbanising landscapes.

\section{Conclusion}

To have any affect on the health of people in urban environments, urban society will require the integration of new urban science knowledge into urban planning and the design and construction of healthier homes, workplaces, community centres, recreation areas, mobility and transport infrastructure. Our built form, the basic template in which we live out the majority of our lives and social interactions, must be planned, designed and constructed to encourage, not hinder, healthy behavioural changes in food availability, mobility options, workplace practices and lifestyle choices. In a broader sense, an urban science agenda is needed not only to inform urban policy, planning and design but to also educate people about the consequences of and trade-offs around the choices they make. In the end, cities, as engines of creativity and innovation, may also be our best hope for providing solutions to many of these pressing problems and long-term sustainability issues. ${ }^{21}$

For more information:

CSIRO Sustainable Ecosystems

http://www.csiro.au/org/cse.html

ECOS Magazine http://www.publish.csiro.au/?nid = 214

\section{References}

1. Grimm NB, Grove JM, Pickett STA, Redman CL. Integrated approaches to long term studies of urban ecological systems. Bioscience 2000; 50(7): 571-84. doi:10.1641/00063568(2000)050[0571:IATLTO]2.0.CO;2

2. Cronon W. Nature's metropolis: Chicago and the great west. New York: W. W. Norton and Company, 1991.
3. Thayer RJ Jr. LifePlace: bioregional thought and practice. Berkeley: University of California Press, 2003.

4. Tainter J. The collapse of complex societies. Cambridge: Cambridge University Press, 1990.

5. Diamond J. Collapse: how societies choose to fail or succeed. New York: Viking Penguin, 2005.

6. Millennium Ecosystem Assessment. Ecosystems and human well-being: synthesis. Washington DC: Island Press, 2005.

7. Porter D. Health, civilization, and the state: a history of public health from ancient to modern times. New York: Routledge, 1999.

8. McMichael AJ. Human frontiers, environments, and disease. Cambridge: Cambridge University Press, 2001.

9. Pickett STA, Birch WL Jr, Dalton SE, Foresman TW. Integrated urban ecosystem research. Urban Ecosyst 1997; 1: 183-4. doi:10.1023/A:1018579628818

10. Newton PW, Baum S, Bhatia K, Brown SK, Cameron AS, Foran B, et al. Human settlements, Australia State of the Environment Report 2001 (Theme Report). Melbourne: CSIRO Publishing on behalf of the Department of the Environment and Heritage, Canberra, 2001.

11. Butler CD, Corvalan CF, Koren HS. Human health, well-being, and global ecological scenarios. Ecosystems 2005; 8: 153-62. doi:10.1007/s10021-004-0076-0

12. Jackson LE. The relationship of urban design to human health and condition. Landsc Urban Plan 2003; 64: 191-200. doi:10.1016/S0169-2046(02)00230-X

13. Jackson LE, Hilborn ED, Thomas JC. Towards landscape design guidelines for reducing Lyme disease risk. Int $J$ Epidemiol 2006; 35: 315-22. doi:10.1093/ije/dyi284

14. Allenby B, Fink J. Towards inherently secure and resilient societies. Science 2005; 309: 1034-6.

15. Vale LJ, Campanella TJ, editors. The resilient city: how modern cities recover from disaster. Oxford: Oxford University Press, 2005.

16. Viljoen A, editor. Continuous productive urban landscapes: designing urban agriculture for sustainable cities. Oxford: Architectural Press, 2005.

17. Walker B, Holling CS, Carpenter SR, Kinzig A. Resilience, adaptability and transformability in social-ecological systems. Ecol Soc 2004; 9(2): 5. [online] URL: http://www.ecologyandsociety.org/vol9/iss2/art5 [Verified 23 April 2007].

18. Hamilton C, Denniss R. Affluenza: when too much is never enough. Sydney: Allen and Unwin, 2005.

19. Berkes F, Colding J, Folke C, editors. Navigating socialecological systems: building resilience for complexity and change. Cambridge: Cambridge University Press, 2003.

20. Pickett STA, Birch WL Jr, Grove JM. Interdisciplinary research: maintaining the constructive impulse in a culture of criticism. Ecosystems 1999; 2: 302-7. doi:10.1007/ s100219900081

21. Pearce F. Ecopolis now: forget the rural idyll - urban living may be the best way to save the planet. New Scientist 2006; 2556: $36-42$. 


\section{Checklist for healthy and sustainable communities}

\author{
Anthony G. Capon ${ }^{\mathrm{A}, \mathrm{B}, \mathrm{D}}$ and Edward J. Blakely \\ A Australian Health Policy Institute, The University of Sydney. \\ ${ }^{\mathrm{B} N a t i o n a l ~ C e n t r e ~ f o r ~ E p i d e m i o l o g y ~ a n d ~ P o p u l a t i o n ~ H e a l t h, ~}$ \\ The Australian National University. \\ ${ }^{\mathrm{C}}$ Planning Research Centre, The University of Sydney. \\ DCorresponding author.Email: acapon@med.usyd.edu.au
}

\begin{abstract}
This paper describes a 10-point checklist for the planning and development of healthy and sustainable communities. The 10 domains in the checklist are essentially physical characteristics of places. Each domain has relevance to the health of people living in the place, and to the sustainability of the environment. The checklist is intended as a tool for those who plan, develop and manage urban environments. Such tools can be valuable for assessing the health and environmental impacts of decisions made by urban and transport planners, and businesses engaged in land development and infrastructure projects.
\end{abstract}

The urban environment is an important determinant of health. ${ }^{1}$ Obesity is a good example of how environmental factors can affect health. Obesity results from an energy imbalance: consuming more energy (food) than is expended through physical activity.

In high-income countries such as Australia, advances in design and engineering during the past 30 years have reduced the need for heavy work and physical activity in daily life. For most people, work is now more sedentary than it was for previous generations. Recreation is also increasingly sedentary. Watching television and playing video games are replacing bike-riding and outdoor games. Increasing amounts of energy from fossil fuels are being used to propel people around their environment (motor vehicles, escalators and lifts.) At the same time, at least as much food is being consumed. There is an increasing reliance on highly processed and convenience foods, which often have high energy content. All of this is making people fat. Further, as a consequence of these changes, excessive carbon dioxide emissions are being produced and this is warming the planet.

Improving the sustainability of urban development will have benefits for human health. ${ }^{2,3}$ In this paper, we argue for the integration of human health considerations with environmental considerations when developing policy for urban and regional planning and sustainability. We present a 10-point checklist as a guide for the development of healthy human habitat. The goal should be to minimise ecological impact while maximising the human experience, including health and well-being. The checklist focuses on characteristics of places rather than people because planners and developers can influence these.

\section{Ten-point checklist for healthy and sustainable communities \\ 1. Outdoor air quality}

Air pollution in Sydney is known to exacerbate asthma. ${ }^{4}$ The main source of outdoor air pollutants in Australian urban environments is motor vehicle emissions. Improved motor vehicle emission controls have reduced emissions for each kilometre travelled; however, the total number of kilometres travelled is increasing. Until there is a reduction in the total number of kilometres travelled, air pollution will remain a health issue in Australian cities.

Urban planning and public health interventions to reduce dependence on motor vehicles and improve air quality include:

- locating jobs, services, schools and shops close to where people live;

- promoting active modes of transport (walking and cycling); and

- providing mass transit options.

\section{Water supply and sanitation}

Ensuring safe drinking water is a traditional public health function. ${ }^{5}$ The drying of the Australian climate has focused attention on water supply and demand. The NSW Government has policies to reduce household water consumption (including restrictions on watering of gardens and promotion of dual-flush toilets and low-flow shower heads). New water supply options are being considered. Recycled water can be safely used in drinking water supplies. Public health professionals have roles in the risk assessment, management and communication about water reuse.

\section{Housing and buildings}

Housing is an important determinant of the ecological footprint of a city. The number of people living in apartments and town houses in Australia has increased exponentially since the 1970s. This has been driven by lifestyle choices, increasing land costs and the trend towards smaller households. The NSW Government has policies to 
reduce energy and water use in new and renovated homes, including Building and Sustainability Index (BASIX) ${ }^{6}$ certification.

Housing and building characteristics with implications for the health of people and the environment include: solar access; indoor air quality; ventilation to minimise the need for air conditioning; reuse of building materials; sustainable materials; avoidance of harmful chemical exposures; on-site reuse of water and alternative sanitation options (such as composting toilets). All communities should have a system equivalent to BASIX to guide new and retro-fit developments at both the building and the neighbourhood levels.

There are benefits from having a mix of housing types and prices in any community, ensuring housing options suitable throughout the life-cycle (including options for those with disabilities). For example, this allows elderly people to move within their community as their housing needs change. They need not leave their established social network.

\section{Food}

A public culture of food brings vitality and conviviality to urban life. ${ }^{7}$ There are health benefits from food shops (fruit and vegetables, meat and fish, daily grocery items) and cafes being in close proximity to where people live. People can walk or cycle to these food outlets, where they can connect with others in their community. This is particularly important for the elderly and disabled people who may not have access to motor vehicles.

Bringing food to people, rather than expecting people to travel by motor vehicle to a regional shopping centre to purchase food, can also reduce carbon dioxide emissions. Such food businesses need a customer base to be financially viable. Locating the businesses on mass transit routes will bring customers to the shops. Economic viability may also be improved by increases in residential density.

Food production in urban areas will be increasingly important as liquid fossil fuels become more expensive. Local production also reduces transport costs. It can enable city dwellers to learn about food production and have contact with nature. Urban agriculture can reduce the intensity of urban heat islands. Growing food in a communal way, in community gardens and city farms, breaks down barriers between people and stimulates a sense of pride in the local environment. ${ }^{8}$ Every jurisdiction should have a food policy to promote local food production and improve access to healthy food. ${ }^{9}$

\section{Local shops and services}

In addition to food shops, there are benefits from having access to other shops and services in our local area, includ- ing primary health care. Shops, services and other destinations can encourage physical activity, social interaction and conviviality. They can also reduce motor vehicle use. However, the emergence of large, stand-alone, regional shopping centers since the 1970s has affected the economic viability of local shops and services. The impact of these changes on our health and well-being warrant further investigation. ${ }^{10}$

\section{Schools and other educational institutions}

Quite apart from what is learnt in schools, including life skills and health literacy, there are health benefits associated with the physical presence of schools within communities. Schools can provide an important social focus in communities. Children, parents and grandparents can develop a social network around the school. Schools also present an unparalleled opportunity to promote children's health. ${ }^{11}$ When schools are located close to children's homes, and when there are safe pathways to the school, children are more likely to walk or cycle to school.

\section{Community spaces}

Spaces (both outdoor and indoor) for recreation and social interaction are a valuable community resource. Parks and community halls are places where groups can meet, play and organise themselves to work together on projects and activities. People who have good access to attractive open spaces are more likely to be physically active. ${ }^{12}$ Governments should place more emphasis on the public domain in Australia, as increasing numbers of people live in apartments and town houses.

Public health workers are advocates for regulation to ensure safety in community spaces; however, care should be taken to avoid over-regulation. Opportunities for children to explore their community unsupervised and take reasonable risks can aid the development of self-esteem and life skills. While rising public indemnity insurance costs are an issue for governments, regulations can reduce fun, informality and spontaneity.

\section{Transport and street connectivity}

Active transport (walking and cycling) is good for our physical and mental health. It also reduces carbon dioxide emissions. People are more likely to walk or cycle if there are destinations of interest in the community, such as shops, services and parks. ${ }^{13}$ Street connectivity is another determinant of the likelihood of walking. ${ }^{2}$ Safe pathways to walk and cycle are essential. Pathways should be well maintained and appropriately lit to reduce the likelihood of slips, trips and other injuries. It is not practical to walk or cycle to work if the job is a long way from home.

Mass transit is good public policy. It is good for health (because it is possible to walk to the bus, tram or train stop), good for the environment (because it reduces 
carbon dioxide emissions) and good for business (because it reduces the cost of traffic congestion.) Mass transit is particularly good for young people, the elderly and the disabled, who may not have access to a motor vehicle.

\section{Communication technology}

Modern communication technologies are essential urban infrastructure. The telephone (whether fixed-line or mobile) connects people with a social network and with work and business opportunities. High-speed internet services enable access to information for work, education and recreation. It is now possible to order a wide range of food and other products via the internet for home delivery, which is of particular value for disabled people. Care has to be taken to ensure that home delivery does not compromise the social and physical activity that accompanies shopping trips.

\section{Economy and employment}

Historically, there was a public health imperative to separating residential areas from employment zones in cities. In particular, industrial point-sources of air pollution were adversely affecting health. In post-industrial societies such as Australia, this is no longer the case. Arguably, there are now public health and environmental imperatives to reintegrate life and work. If people live close to where they work, there can be benefits to their health and the health of the environment. Long commuting times can be a source of stress, can adversely affect health and increase carbon dioxide emissions.

Local economic development is a tool to create locally based jobs. Each community needs to find ways that it can incubate new ideas and new jobs. Communities should have local job generation programs and measure job creation as a central tenet of community well-being not simply the number of people employed. ${ }^{14}$

\section{Implications for the health of people and the health of the environment}

The 10 domains in the checklist are essentially physical attributes of places. These attributes affect our health by influencing:

- levels of physical activity;

- food choices;

- safety and sense of security;

- sound and noise exposure;

- thermal exposure (heat and cold);

- exposure to air and water pollutants and contaminated land;

- access and participation (especially for youth, disabled people, elderly);

- social connection;

- conviviality;

- opportunities for contact with nature; and
- time use (commuting, with family, for recreation, in community).

Similarly, these 10 attributes of places affect the health of the environment through:

- energy consumption;

- water consumption;

- other resource requirements;

- ecosystem and biodiversity impacts;

- carbon dioxide and other greenhouse gas emissions; and

- the production of other pollutants and waste.

\section{Discussion}

This checklist for healthy and sustainable communities demonstrates the diverse range of factors in our urban environment that affect our health. Each of the items on the checklist is in some way interdependent on other items. This means we need to consider the urban environment as a system. The checklist could be further developed as a policy and planning tool for urban planners, sustainability planners and public health practitioners. It might also be developed as an audit tool for the land development industry.

Human health impacts (positive and negative) should be accounted for in the planning, development and management of our urban environments. Equity-focused, health impact assessments provide a framework to improve decision making. ${ }^{15}$ Urban planners make many decisions every day and not all of these can be subject to health impact assessment. There is a case for strengthening the way human health is considered in education programs in urban planning. Similarly, there is a case for strengthening public health education programs by including urban planning in the curriculum. Joint training programs for the existing planning and public health workforce should be encouraged.

There is no ideal urban environment. The circumstances of individuals, such as age, family relationships, health status, employment options and recreational interests will determine the suitability of urban environments. In choosing where to live (whether renting or buying), there will be trade-offs. Careful consideration should be given to resources available in the local area. This will reduce the need to travel and this in turn will reduce carbon dioxide emissions.

\section{Conclusion}

Planning, developing and managing our urban environments more wisely will benefit health and improve environmental outcomes. Environmental concerns are currently at the top of the political agenda both in Australia and internationally. It is imperative that we move beyond the current high-consumption phase of human history to a 
biosensitive phase, ${ }^{16}$ where human activities are in balance with nature. To ensure a successful transition, it is essential that considerations of the health of people are integrated with those of the environment.

\section{Acknowledgement}

This work was enabled by financial support from the Oxford Health Alliance (http://www.oxha.org).

\section{References}

1. Galea S, Vlahov D. Urbanization. In: Frumkin H, editor Environmental health: from global to local. San Francisco: Jossey-Bass, 2005. pp. 387-413.

2. Frumkin H, Frank L, Jackson R. Urban sprawl and public health. Designing, planning and building for healthy communities. Washington: Island Press, 2004.

3. Smart Growth America. Washington: Smart Growth America. Available at http://www.smartgrowthamerica.org/ [Verified 22 April 2007].

4. Jalaludin B. Cars, trucks and buses, the urban environment and ambient air pollution - what's the connection? In: Johnson C, editor. Healthy environments. Sydney: Government Architect's Publications, 2004. pp. 18-25.

5. Cowie C. Water quality. In: Johnson C, editor. Healthy environments. Sydney: Government Architect's Publications, 2004. pp. 26-35.

6. NSW Department of Planning. BASIX - Building Sustainability Index. Available at http://www.basix.nsw.gov.au/ information/index.jsp [Verified 9 April 2007].
7. Franck KA. The city as dining room, market and farm. Architectural Design 2005; 75: 5-10. doi:10.1002/ad.70

8. Doron G. Urban agriculture: small, medium, large. Architectural Design 2005; 75: 52-9. doi:10.1002/ad.76

9. Webb K, King L. Food, nutrition and the built environment. In: Johnson C, editor. Healthy environments. Sydney: Government Architect's Publications, 2004. pp. 46-55.

10. Dixon J. Adding value(s): a cultural economy analysis of supermarket efforts. In: Germov J, Williams L, editors. A sociology of food and nutrition: the social appetite. 2nd Edn. New York: Oxford University Press, 2004. pp. 96-115.

11. Frumkin H, Geller R, Rubin IL, Nodvin J, editors. Safe and healthy school environments. New York: Oxford University Press, 2006.

12. Giles-Corti B, Donovan RJ. Relative influences of individual, social environmental, and physical environmental correlates of walking. Am J Public Health 2003; 93: 1583-9.

13. Owen N, Humpel N, Leslie E, Bauman A, Sallis JF. Understanding environmental influences on walking: review and research agenda. Am J Prev Med 2004; 27: 67-76. doi:10.1016/j.amepre.2004.03.006

14. Blakely EJ, Bradshaw TK. Planning local economic development: theory and practice. 3rd Edn. Thousand Oaks: Sage Publications, 2002.

15. Harris E. Contemporary debates in health impact assessment: What? Why? When? N S W Public Health Bull 2005; 16: $107-8$.

16. Boyden S. The biology of civilisation. Sydney: UNSW Press, 2004. 


\section{Pertussis in New South Wales, 1993-2005: the impact of vaccination policy on pertussis epidemiology}

\section{Kerri A. Viney ${ }^{\mathrm{A}, \mathrm{C}}$, Jeremy M. McAnulty ${ }^{\mathrm{A}}$ and Sue Campbell-Lloyd ${ }^{\mathrm{B}}$}

ACommunicable Diseases Branch, NSW Department of Health. ${ }^{\mathrm{B}}$ AIDS/Infectious Diseases Branch, NSW Department of Health. ${ }^{\mathrm{C}}$ Corresponding author.Email: kvine@doh.health.nsw.gov.au

\begin{abstract}
Objective: To assess whether changes in vaccination policy have affected the epidemiology of pertussis in NSW between 1993 and 2005. Methods: Surveillance data from the NSW Notifiable Diseases Database was reviewed for the period. Results: 35695 cases of pertussis were notified; annual incidence rates varied from 18.4 to 84.2 per 100000 people. The highest rates of pertussis were consistently found in infants aged 0-6 months. Rates of disease in other age groups changed markedly over the study period, with high rates currently observed in adult age groups. Conclusions: New strategies may be needed to control pertussis in infants and in adults who now comprise the largest proportion of cases.
\end{abstract}

Pertussis, or whooping cough, is a highly contagious disease caused by the bacteria Bordetella pertussis. The disease is characterised by paroxysmal cough, inspiratory whoop and post-tussive vomiting. ${ }^{1}$ Pertussis is transmitted via direct contact with discharges from the respiratory tract of infected individuals (probably via droplets), and the incubation period is 9-10 days on average. ${ }^{2}$ A secondary attack rate of $90 \%$ has been recorded in non-immune household contacts. ${ }^{2}$ Worldwide, the incidence of pertussis has been reported to be highest in children under 5 years, except where infant vaccination programs have achieved consistently high vaccination rates. ${ }^{2}$

In NSW, there have been several changes to the immunisation schedule affecting pertussis vaccination in recent years. From 1985, a combined whole cell diphtheria, tetanus and pertussis vaccine (DTPw) was included in the immunisation schedule at ages 2, 4 and 6 months, with a booster at 18 months. ${ }^{3}$ In 1994, a fifth dose was introduced into the schedule, which was given before school entry (at 4-5 years). In 1997, the fourth and fifth doses of DTPw were replaced by an acellular formulation (DTPa diphtheria, tetanus, acellular pertussis) and in 1999, all five doses were given as DTPa. ${ }^{4}$ In 2004, an adolescent booster vaccine (dTpa - diphtheria, tetanus, acellular pertussis) was introduced for 15-17 year olds and in NSW this was offered to all 11-18 year olds as part of the school based immunisation program. Also in 2004, the booster for 18 month olds was no longer recommended. ${ }^{3}$

Under the NSW Public Health Act 1991, cases of pertussis are notified by doctors, hospitals, laboratories, schools and childcare facilities. ${ }^{5}$ Prior to January 2006 public health unit staff routinely followed up all reported cases of pertussis; since January 2006 only cases aged less than 20 years are investigated.

We conducted a descriptive study to assess the impact of changes to vaccination policy on pertussis epidemiology in NSW.

\section{Methods}

We reviewed surveillance data from the NSW Notifiable Diseases Database (NDD) for the period 1 January 1993 to 31 December 2005. For our review, a case of pertussis was defined according to the national case definition. ${ }^{6}$

Annual notification rates were calculated using mid year population estimates from the Australian Bureau of Statistics. Notification rates and frequencies were calculated using SAS (version 8.2 SAS Institute, Cary, NC, USA). Cases were analysed by date of onset, method of diagnosis, area of residence, age group, gender and mortality. Data on mortality were taken from NDD. Age groups analysed were: 0-6 months, 7-11 months, 1-4 years, 5-11 years, 12-17 years, 18-24 years, 25-44 years, 45-64 years and 65 years and older. Age groups were chosen to reflect ages at which vaccination occurs and stages of adulthood.

To assess the impact of changes in vaccination policy on age specific disease incidence, the above case characteristics were compared over 5 time periods:

(1) before the introduction of the fifth dose (1993-94)

(2) after the introduction of the fifth dose (1995-98) 
(3) after the introduction of acellular vaccines for all five doses (1999-2003)

(4) during the school-based adolescent booster campaign (2004) and

(5) after the introduction of the adolescent booster (2005).

\section{Results}

From 1 January 1993 to 31 December 2005, a total of 35695 cases of pertussis were reported in NSW (an average of 2746 cases each year). Fig. 1 displays the number of notifications during the study period; notifications peaked seven times, in November 1993, November 1997, September 2000, August 2001, November 2003, September 2004, and in August 2005.

Annual incidence rates per 100000 people ranged from a low of 18.4 in 1996 to a high of 84.2 in 2005. The overall incidence rate over the 13 years was 42.8 per 100000 people. Incidence rates varied widely between Area Health Service of residence and by year of notification. Metropolitan Sydney had an incidence rate of 39.8 per 100000 people, compared with 47.1 for the rest of NSW. Of all notified cases, females comprised $56.1 \%$ and males $43.7 \%$. There was a slight increase in the proportion of female cases reported over time, and in 2005 this reached its highest at $60 \%$.

Table 1 displays the number of pertussis cases and incidence for the five periods studied, and also provides these figures by gender, age group, method of diagnosis, location of residence and number of deaths. Fig. 2 displays the incidence rates of pertussis per 100000 people for six age groups by the study periods, and Fig. 3 displays the proportion of pertussis cases by age group and study period. These results are further described below.

\section{1993-94}

In the 1993-94 period, 2938 pertussis cases were notified (incidence rate, 24/100000). The highest notification rates were in infants aged $0-6$ months followed by infants aged 7-11 months and children aged 5-11 years. The lowest notification rates were in those aged 65 years and older. The predominant method of diagnosis was serology. No deaths were recorded during this period.

\section{1995-98}

Between 1995 and 1998, 9078 cases of pertussis were notified (incidence rate, 35.9/100000). The highest notification rates were in infants aged 0-6 months, followed by primary school age children (5-11 years), and adolescents aged 12-17 years. Compared with 1993-94, rates in all adult age groups increased, rates in school age children increased (by approximately 50\%) and rates in infants aged 7-11 months decreased. Rates in children aged 1-4 years old showed almost no change. In 1995-98 the predominant method of diagnosis was serology. Five deaths were recorded in infants aged less than 12 months of age, two of whom were less than 1 month old. ${ }^{7}$

\section{1999-2003}

Between 1999 and 2003, 14317 cases of pertussis were notified (incidence rate, 43.1/100000). The highest rates

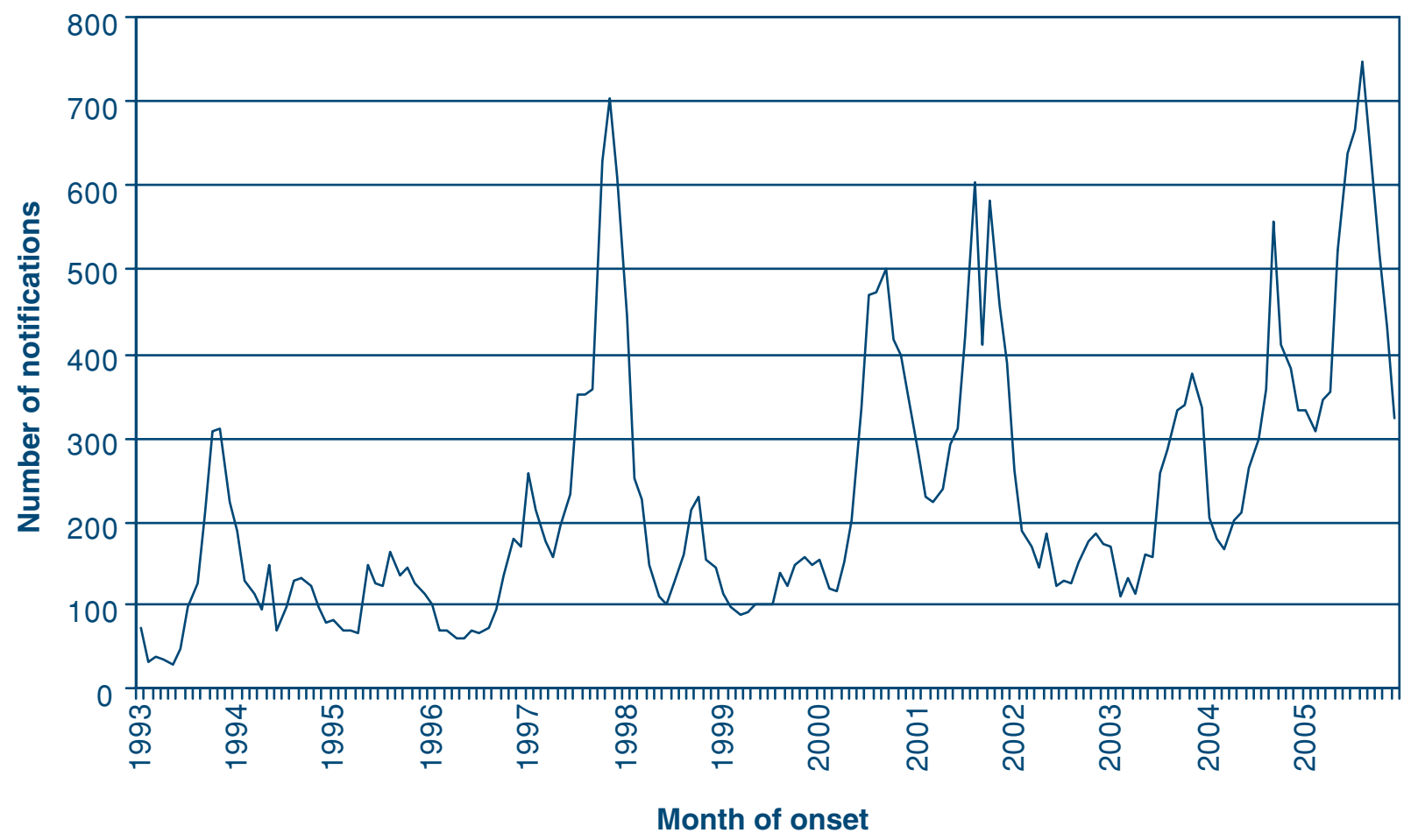

Fig. 1. Number of pertussis notifications by month of onset, NSW, 1993-2005. 
were in infants aged between 0-6 months, followed by adolescents and primary school age children. Compared with 1995-98, rates in children aged 5-11 years decreased by $38 \%$. Rates in children aged between $1-4$ years and in infants aged between 0-6 months also decreased, and rates in cases aged over 11 years increased, mainly in 12-17 year olds (by 109\%). Two-thirds of cases were diagnosed by serology and $12 \%$ were diagnosed by both polymerase chain reaction (PCR) and culture (PCR was introduced as a diagnostic method in 1999). Three deaths were recorded; one in a 2-month-old infant and two in adults aged 75 and 78 years.

\section{2004}

In 2004, there were 3563 cases of pertussis (incidence rate, 52.3/100000). The highest rates were in infants aged 0-6 months, followed by adolescents and adults aged 45-64 years (for the first time, rates in an adult age group became the third highest). Rates in other adult age groups also increased, most notably in adults aged 65 years and over, where rates increased by $134 \%$. Just over threequarters of notifications were diagnosed by serology and
$13 \%$ by PCR. There was one death due to pertussis in a 95-year-old person.

\subsection{5}

In 2005,5799 cases of pertussis were notified (incidence rate, 84.2/100000). Highest notification rates were in infants aged 0-6 months, followed by adults aged 45-64 years and adults aged 25-44 years. Compared to 2004, rates decreased by over $50 \%$ in adolescents and by $32 \%$ in children aged 5-11 years. Rates increased for all adult age groups and for children under 1 year of age, when compared to 2004. In 2005, almost all cases (85\%) were diagnosed by serology while $7 \%$ were diagnosed by PCR. No deaths were recorded in 2005 .

\section{Discussion}

The age distribution of pertussis notifications in NSW changed over the study period. In 1993-94, approximately one-third of cases occurred in adults, by 2005 this had increased to almost $90 \%$ (Fig. 3). The incidence of pertussis in children aged less than 12 years declined, except for $0-6$ month olds where there was a slight increase

Table 1. Characteristics of pertussis cases in NSW, 1993-2005, by study periods

\begin{tabular}{|c|c|c|c|c|c|c|c|c|c|c|c|c|c|c|c|}
\hline & \multicolumn{3}{|c|}{ 1993-94 } & \multicolumn{3}{|c|}{ 1995-98 } & \multicolumn{3}{|c|}{ 1999-2003 } & \multicolumn{3}{|c|}{2004} & \multicolumn{3}{|c|}{2005} \\
\hline & $n$ & $\%$ & $\begin{array}{c}\text { Rate/ } \\
100000\end{array}$ & $n$ & $\%$ & $\begin{array}{l}\text { Rate/ } \\
100000\end{array}$ & $n$ & $\%$ & $\begin{array}{l}\text { Rate/ } \\
100000\end{array}$ & $n$ & $\%$ & $\begin{array}{c}\text { Rate/ } \\
100000\end{array}$ & $n$ & $\%$ & $\begin{array}{c}\text { Rate/ } \\
100000\end{array}$ \\
\hline \multicolumn{16}{|l|}{ Gender } \\
\hline Male & 1362 & 46.4 & 22.7 & 4089 & 45.1 & 33 & 6360 & 44.4 & 39.1 & 1500 & 42.1 & 44.8 & 2295 & 39.6 & 67.8 \\
\hline Female & 1572 & 53.5 & 25.9 & 4942 & 54.7 & 39.6 & 7955 & 55.6 & 48.2 & 2061 & 57.8 & 60.9 & 3496 & 60.3 & 102.3 \\
\hline Unknown & 4 & 0.1 & - & 20 & 0.2 & - & 2 & 0 & - & 2 & 0.1 & - & 8 & 0.1 & - \\
\hline \multicolumn{16}{|l|}{ Age group ${ }^{A}$} \\
\hline $0-6$ months & 183 & 6.2 & 208.1 & 411 & 4.5 & 237.3 & 464 & 3.2 & 216.5 & 71 & 2 & 164.4 & 94 & 1.6 & 218.1 \\
\hline 7-11 months & 65 & 2.2 & 73.9 & 69 & 0.8 & 39.8 & 88 & 0.6 & 41.1 & 16 & 0.4 & 37.1 & 22 & 0.4 & 51 \\
\hline $1-4$ years & 347 & 11.8 & 49.3 & 694 & 7.6 & 49.2 & 647 & 4.5 & 37.1 & 157 & 4.4 & 46.2 & 152 & 2.6 & 44.8 \\
\hline 5-11 years & 884 & 30.1 & 73.6 & 2670 & 29.4 & 108.6 & 2139 & 14.9 & 67.6 & 205 & 5.8 & 32.9 & 141 & 2.4 & 22.5 \\
\hline $12-17$ years & 379 & 12.9 & 37.7 & 1225 & 13.5 & 59.3 & 3324 & 23.2 & 124 & 503 & 14.1 & 92 & 223 & 3.8 & 40.4 \\
\hline $18-24$ years & 133 & 4.5 & 10.2 & 479 & 5.3 & 19.2 & 799 & 5.6 & 26 & 236 & 6.6 & 36.7 & 423 & 7.3 & 65.8 \\
\hline $25-44$ years & 568 & 19.1 & 15.3 & 2007 & 22.1 & 26.2 & 3471 & 24.2 & 35.2 & 970 & 27.2 & 49.2 & 1900 & 32.8 & 96.1 \\
\hline 45-64 years & 267 & 9.1 & 10.8 & 1134 & 12.5 & 21.2 & 2614 & 18.3 & 34.6 & 1023 & 28.7 & 63.4 & 2080 & 35.9 & 125.4 \\
\hline $65+$ years & 112 & 3.8 & 7.5 & 389 & 4.3 & 12.3 & 770 & 5.4 & 18 & 382 & 10.7 & 42.1 & 764 & 13.2 & 82.9 \\
\hline \multicolumn{16}{|l|}{ Method of diagnosis } \\
\hline Serology & 1364 & 46.4 & - & 5533 & 60.9 & - & 9541 & 66.6 & - & 2728 & 76.6 & - & 4952 & 85.4 & - \\
\hline PCR & 0 & 0 & - & 0 & 0 & - & 1747 & 12.2 & - & 478 & 13.4 & - & 405 & 7 & - \\
\hline Clinical & 30 & 1 & - & 556 & 6.1 & - & 1755 & 12.3 & - & 227 & 6.4 & - & 182 & 3.1 & - \\
\hline Culture & 183 & 6.2 & - & 339 & 3.7 & - & 260 & 1.8 & - & 21 & 0.6 & - & 23 & 0.4 & - \\
\hline Other/unknown & 1361 & 46.4 & - & 2650 & 29.3 & - & 1014 & 7.1 & - & 109 & 3.1 & - & 237 & 4.1 & - \\
\hline \multicolumn{16}{|l|}{ Residence } \\
\hline Metro Sydney & 1602 & 54.5 & 22.7 & 4866 & 53.6 & 33.2 & 7158 & 50 & 37.1 & 2109 & 59.2 & 53.1 & 3791 & 65.4 & 94.3 \\
\hline Other NSW & 1336 & 45.5 & 26.7 & 4211 & 46.4 & 41 & 7159 & 50 & 53.2 & 1454 & 40.8 & 52.7 & 2008 & 34.6 & 72.1 \\
\hline Deaths & 0 & 0 & 0 & 5 & 0.05 & 0.02 & 3 & 0.02 & 0 & 1 & 0.03 & 0 & 0 & 0 & 0 \\
\hline Total & 2938 & & & 9078 & & & 14317 & & & 3563 & & & 5799 & & \\
\hline
\end{tabular}

AOne person in 1999-2003 had age group missing. 
(Fig. 2). This increase occurred despite the introduction of a fifth dose, an adolescent booster vaccination and the introduction of acellular vaccinations.

Infants aged 0-6 months are at greatest risk of pertussis because they are partially immunised; for example, the effectiveness of acellular pertussis vaccines in preventing hospitalisation of children aged 2-32 months has been demonstrated to be $68.1 \%$ after one dose of vaccine, $91.8 \%$ after the second dose, and $99.8 \%$ after three doses. ${ }^{8}$ In addition, the protective efficacy of three doses of acellular vaccine is approximately $84 \% .{ }^{9}$ Higher rates observed in infants in 2005 may reflect epidemic activity; pertussis epidemics typically occur every 3-4 years in NSW and the last recorded epidemic was between 2000-02. ${ }^{10}$ Higher rates in infants may also be due to infants being infected by older adults. Rates of pertussis have increased in all adult age groups aged 18 years and older. There was a decrease in rates in high school aged children (12-17 years) after the introduction of the adolescent school-based immunisation program in 2004.

In countries with high immunisation rates, a greater proportion of pertussis cases are now presenting in adults and adolescents. ${ }^{1,11,12,13}$ In the United States from 1994-96 to 1997-2000, incidence rates in adolescents and adults increased by $62 \%$ and $60 \%$, respectively. ${ }^{14}$ In Canada from 1993-98, the proportion of pertussis cases in adults steadily increased ${ }^{15}$ and in 2000 for the first time in two decades, 10-14-year-old children represented a larger pro- portion of cases (34\%) and had a higher incidence of pertussis than infants or preschool age children $(13 \%) .{ }^{15} \mathrm{In}$ Europe, recent pertussis infection was found to be significantly more likely in adults and adolescents in countries with high immunisation rates. ${ }^{12} \mathrm{~A}$ trend towards pertussis occurring in older age groups has also been documented in NSW in the Hunter/New England Area Health Service. ${ }^{16}$

Despite high vaccination rates in many countries, pertussis continues to circulate. ${ }^{20}$ Reasons for this include: waning immunity following both natural infection and immunisation, ${ }^{11,20,21,22}$ increased recognition of pertussis in adolescents by physicians, ${ }^{1}$ increased use of serology and PCR testing, ${ }^{11}$ improved surveillance, ${ }^{19}$ in some countries the use of a poorly protective vaccine resulting in cohorts of susceptible people, ${ }^{11,15}$ and of course, a real increase in pertussis. ${ }^{19,21}$ The relative contribution of these factors in NSW is unclear, but it is likely to be a combination of many of these factors. From 1995-2004, DTP vaccination rates at age $12-15$ months in NSW have ranged from $83.3 \%$ in 1998 to $92.5 \%$ in $2004 .^{23,24}$

The increase in pertussis in adolescents and adults in NSW is of concern because they may serve as reservoirs of infection for partially immunised infants. ${ }^{13,20,21,25}$ In studies from the United States, ${ }^{26}$ France, ${ }^{27}$ the United Kingdom ${ }^{28}$ and Australia ${ }^{29}$ parents were identified as the source of infection for $34-47 \%$ of infections in infants. Further, studies from several countries including Canada, Denmark, and France indicate that up to $32 \%$ of adults and

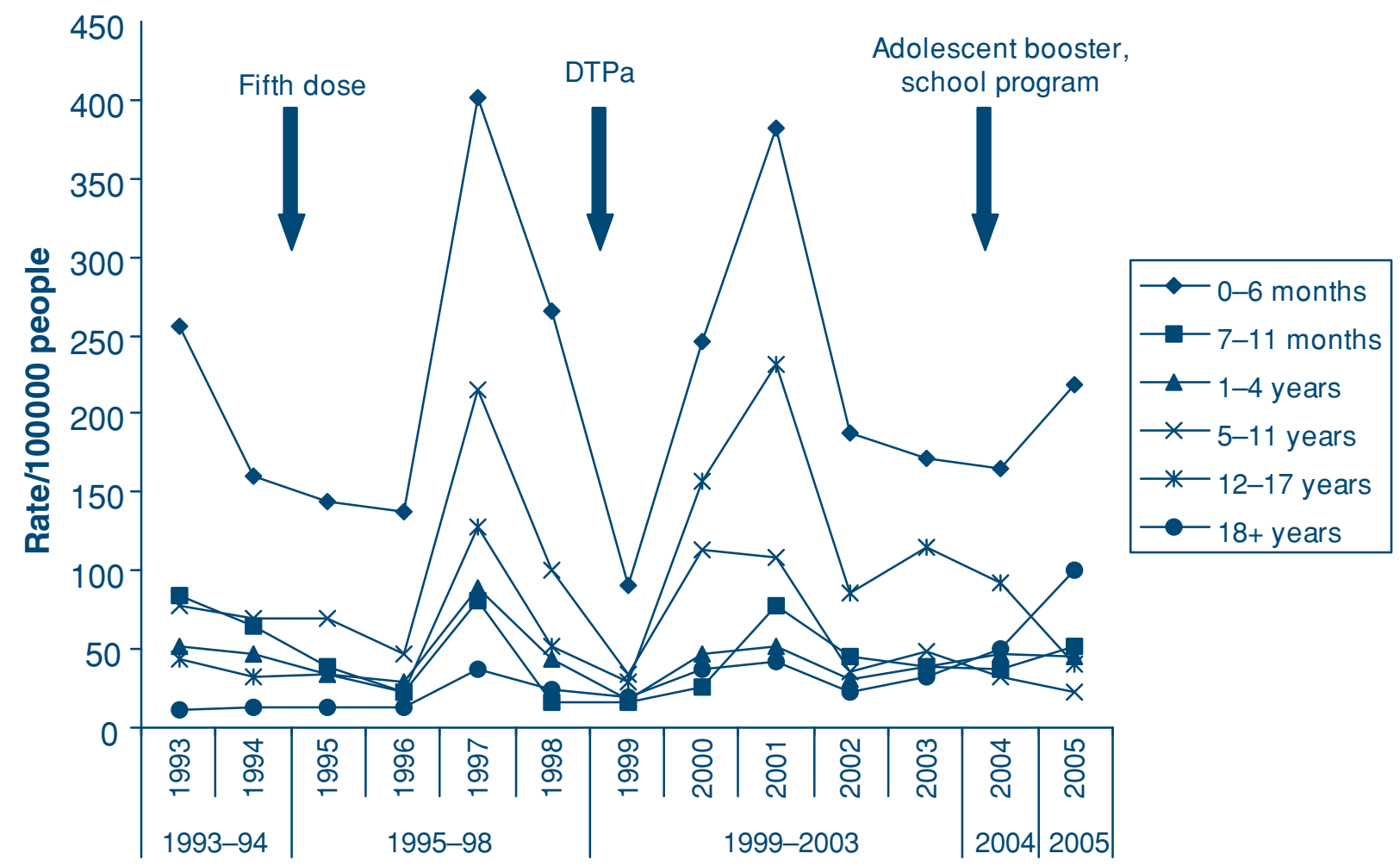

Fig. 2. Incidence rates of pertussis/100000 people by age group at onset and the introduction of changes to the vaccination schedule, NSW, 1993-2005. 
adolescents with a coughing illness of at least 1 week's duration have pertussis. ${ }^{30,31}$ This proportion may change depending on the nature of pertussis activity at the time; during pertussis epidemics this may be higher than at other times. Unpublished NDD data on $15 \mathrm{NSW}$ children aged under 12 months indicates that although for half the source of infection was unknown, an adult was identified as a potential source of infection in $13 \%$ of cases and young children in 33\%. No adolescent was identified as a source.

In recognition of the rising incidence of pertussis in adolescents and adults, and the role they may play in transmission to infants, ${ }^{17}$ Australia, Austria, Canada, France and Germany have incorporated an adolescent booster into their immunisation schedules, ${ }^{18}$ and it is now recommended in the USA. ${ }^{19}$

There are several limitations to this analysis. First, laboratory notification of pertussis began in 1991 and data quality may have improved over time, therefore later data may be more complete than earlier data. Second, following substantial increases in pertussis notifications based on serological testing in 2005, a review of the antibody test was carried out. ${ }^{32}$ The reviewers concluded that the use of the antibody test was likely to have resulted in over diag- nosis of pertussis. ${ }^{32}$ In $2005,85 \%$ of cases were diagnosed using serology and there may have been an over diagnosis of pertussis in this year, particularly in adults.

Serology as a diagnostic method is not recommended in children less than 2 years of age due to its low sensitivity in this age group. ${ }^{5}$ PCR, however, is largely replacing culture for the diagnosis of pertussis. ${ }^{5,33}$ Because PCR and serology are more likely than culture to be positive in both adults and older children with pertussis, the increased availability and use of PCR and serology may contribute to an increase in pertussis cases that may have otherwise been undiagnosed..$^{11,33}$

In NSW, pertussis may now be regarded as a disease primarily of adults although the severest outcomes remain for infants and potentially the elderly. One-third of cases in 2005 occurred in people of childbearing age, and this may pose a risk to unimmunised infants. Rates in adults increased 5-13 fold over the study period, and have increased the most in adults aged 45-64 years; this is of concern as these people may be providing childcare for children or grandchildren. A lack of natural boosting due to less exposure to pertussis may contribute towards waning immunity in adults. ${ }^{31}$ Females now comprise $60 \%$

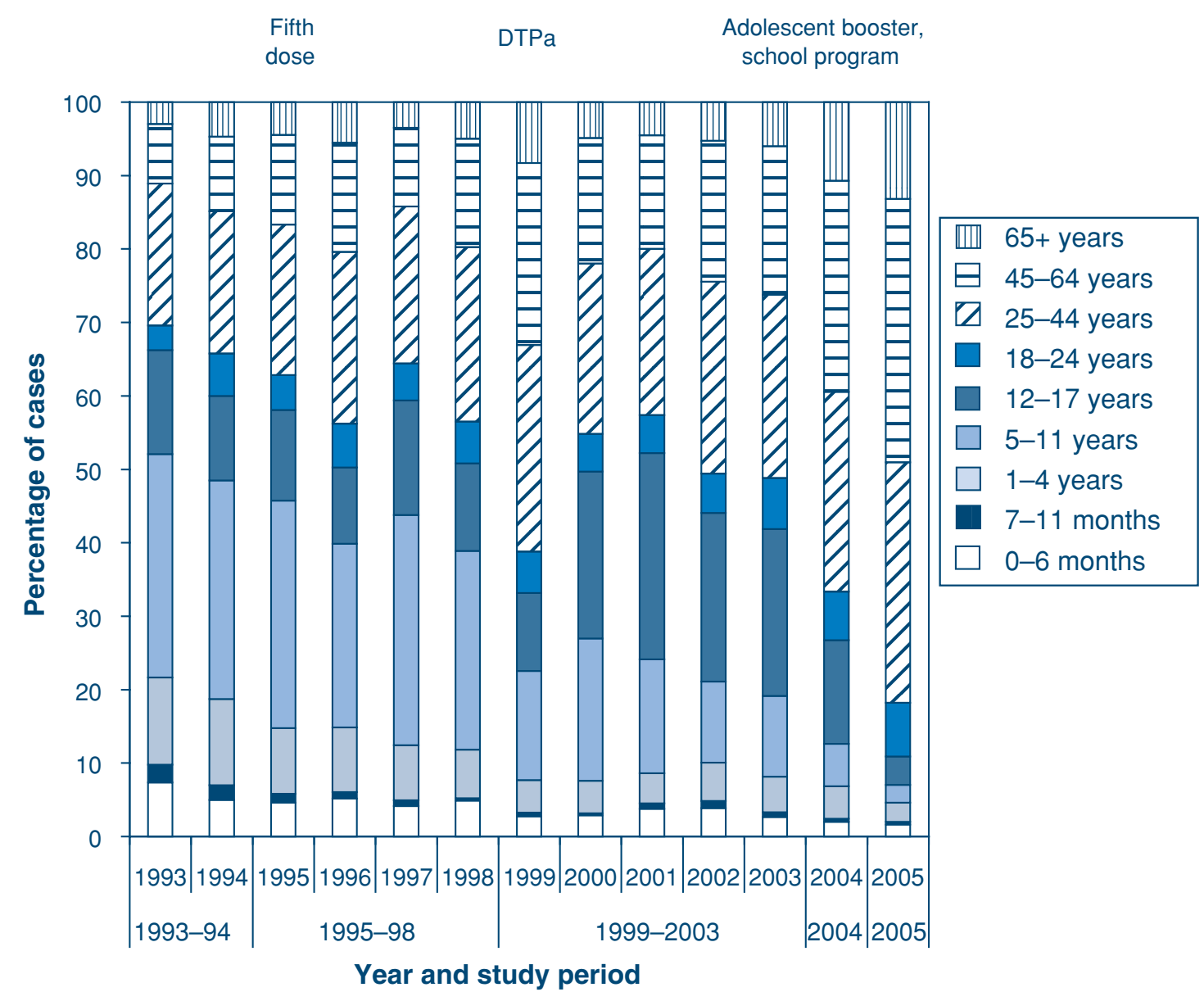

Fig. 3. Proportion of pertussis cases by age group at onset and study period in NSW, 1993-2005. 
of cases and, in their roles as mothers and grandmothers, may pose a risk to infants. Females also make up a large proportion of the health care and childcare workforce, thereby potentially posing an additional risk to infants in child care or health care settings. More data would be useful on the source of infection for infants aged less than 12 months in NSW to assess the impact of adolescent vaccination on those infants. In unpublished NDD data, the source of infection in over $50 \%$ of cases aged less than 12 months in 2006 was unknown.

The National Health and Medical Research Council recommends a booster vaccine for: adolescents; adults before planning pregnancy or as soon as possible after delivery of an infant; adults working with young children (especially for child care workers and health care workers); and adults who express an interest in receiving a booster dose of dTpa (provided that they have received a full course of DTP). ${ }^{34}$ Further, the NSW Department of Health policy states that all employees and other clinical personnel who have contact with clients should receive a dose of an acellular pertussis containing vaccine. ${ }^{35}$

\section{Conclusion}

Rates in infants aged less than 12 months, who are at greatest risk of severe disease and death, have not decreased over the thirteen year study period despite changes to the immunisation schedule. Other strategies may be required to effectively control pertussis in this age group. Vaccination of adolescents in the school based immunisation program may continue to influence rates of disease in infants, ${ }^{36}$ but strengthening of immunisation in new parents, ${ }^{37,38}$ child care and health care workers, ${ }^{37}$ adults planning a pregnancy ${ }^{37}$ as well as grand parents, should be considered further to both decrease rates of disease in infants and reduce morbidity in adults.

\section{References}

1. Centers for Disease Control and Prevention Pertussis-United States, 2001-2003. Morb Mortal Wkly Rep 2005; 54: 1283-6.

2. Heymann DL. Control of communicable diseases manual. 18th ed. Washington DC: American Public Health Association, 2004.

3. National Centre for Immunisation Research and Surveillance. A brief history of vaccination and childhood vaccination practices in Australia. Available at http://www.ncirs.usyd.edu.au/publ/publ-79-histtab1.html [Verified 15 May 2007].

4. Torvaldsen S, Simpson JM, McIntyre PB. Effectiveness of pertussis vaccinations in New South Wales, Australia, 1996-1998. Eur J Epidemiol 2003; 18: 63-9. doi:10.1023/A:1022588118030

5. Health NSW. Notifiable diseases manual. NSW: NSW Health, 2005.

6. Department of Health and Ageing. Australian national notifiable diseases case definitions-pertussis. Available at http://www.health.gov.au/internet/wcms/publishing.nsf/Content /cda-surveil-nndss-casedefs-cd_pertus.htm [Verified 15 May 2007].

7. National Centre for Immunisation Research and Surveillance Vaccine preventable diseases and vaccination coverage in Australia, 1993-1998. Commun Dis Intell 2000; 24: i-83.

8. Juretzko P, von Kries R, Wirsing von Konig CH, Weil J, Giani G. Effectiveness of acellular pertussis vaccine assessed by hospital-based active surveillance in Germany. Clin Infect Dis 2002; 35: 162-7. doi:10.1086/341027

9. Greco D, Salmaso S, Mastrantonio P, Giulianop M, Tozzi AE, Anemona A et al. A controlled trial of two acellular vaccines and one whole-cell vaccine against pertussis. $N$ Engl J Med 1996; 334: 341-8. doi:10.1056/NEJM199602083340601

10. Brotherton J, McAnulty J. A pertussis epidemic in NSW: how epidemiology reflects vaccination policy. N SW Public Health Bull 2003; 14: 77-81.

11. Skowronski D, De Serres G, MacDonald D, Wu W, Shaw C, Macnabb J et al. The changing age and seasonal profile of pertussis in Canada. J Infect Dis 2002; 185: 1448-53. doi: $10.1086 / 340280$

12. Pebody RG, Gay J, Giammanco A, Baron S, Schellekens J, Tischer A et al. The seroepidemiology of Bordetella pertussis infection in Western Europe. Epidemiol Infect 2005; 133(1): 159-71. doi:10.1017/S0950268804003012

13. Grimprel E, Baron S, Levy-Bruhl D, Garnier JM. N'jamkepo E, Guiso N, Begue P. Influence of vaccination coverage on pertussis transmission in France. Lancet 1999; 354: 1699-700. doi:10.1016/S0140-6736(99)01576-7

14. Centers for Disease Control and Prevention Pertussis-United States, 1997 - 2000. Morb Mortal Wkly Rep 2002; 51: 73-6.

15. Ntezayabo B, De Serres G, Duval B. Pertussis resurgence in Canada largely caused by a cohort effect. Pediatr Infect Dis $J$ 2003; 22: 22-7. doi:10.1097/00006454-200301000-00009

16. Durrheim D, Massey P, Carr C, Islam F. The changing epidemiology of pertussis in the Hunter New England Area and potential implications for the immunisation schedule. N S W Public Health Bull 2006; 17(3-4): 48-51.

17. Tan T. Summary: Epidemiology of pertussis. Pediatr Infect Dis J 2005; 24: S35-8. doi:10.1097/01.inf.0000160910. 17950.59

18. Tan T, Trinlade E, Skowronski D. Epidemiology of pertussis. Pediatr Infect Dis J 2005; 24: S10-8. doi:10.1097/01.inf. 0000160708.43944 .99

19. Centers for Disease Control and Prevention Preventing tetanus, diphtheria, and pertussis among adolescents: use of tetanus toxoid, reduced diphtheria toxoid and acellular pertussis vaccines. Morb Mortal Wkly Rep 2006; 55: 1-43.

20. Forsyth K, Tan T, Wirsing von Konig C-H, Caro JJ, Plotkin S. Potential strategies to reduce the burden of pertussis. Pediatr Infect Dis J 2005; 24: S69-74. doi:10.1097/01.inf.0000160917.29723.03

21. Schellekens J, Wirsing von Konig C-H, Gardner P. Pertussis sources of infection and routes of transmission in the vaccination era. Pediatr Infect Dis J 2005; 24: S19-24. doi:10.1097/01.inf.0000160909.24879.e6

22. Wendelboe AM, Van Rie A, Salmaso S, Englund JA. Duration of immunity against pertussis after natural infection or vaccination. Pediatr Infect Dis J 2005; 24: S58-61. doi:10.1097/01.inf.0000160914.59160.41 
23. Australian Bureau of Statistics. Children's immunisation Australia April 1995. Canberra: Australian Bureau of Statistics, 1996.

24. Medicare Australia. Australian childhood immunisation register. 1998-2004. Medicare Australia.

25. Greenberg DP. Pertussis in adolescents: increasing incidence brings attention to the need for booster immunization of adolescents. Pediatr Infect Dis $J$ 2005; 24: 721-8. doi:10.1097/01.inf.0000172905.08606.a3

26. Bisgard KM, Pascaul FB, Ehresmann KR, Miller CA, Cianfrani $\mathrm{C}$, Jennings $\mathrm{CE}$ et al. Infant pertussis: who was the source? Pediatr Infect Dis J 2004; 23: 985-9. doi:10.1097/01.inf.0000145263.37198.2b

27. Baron S, Njamkepo E, Grimprel E. Begue Ps, Desenclos J-C, Drucker J, Guiso N. Epidemiology of pertussis in French hospitals in 1993 and 1994: thirty years after a routine vaccination. Pediatr Infect Dis $J$ 1998; 17: 412-8. doi:10.1097/00006454-199805000-00013

28. Crowcroft NS, Booy R, Harrison T, Spicer L, Britta J, Mok Q et al. Severe and unrecognised: pertussis in UK infants. Arch Dis Child 2003; 88: 802-6. doi:10.1136/adc.88.9.802

29. Elliott E, McIntyre P, Ridley G, Morris A, Massie J, Mceniery J et al. National study on infants hospitalized with pertussis in the acellular vaccine era. Pediatr Infect Dis J 2004; 23: 246-52. doi:10.1097/01.inf.0000116023.56344.46

30. Rothstein E, Edwards E. Health burden of pertussis in adolescents and adults. Pediatr Infect Dis J 2005; 24: S44-7. doi:10.1097/01.inf.0000160912.58660.87
31. Hewlett EL, Edwards KM. Pertussis-not just for kids. $N$ Engl J Med 2005; 352: 1215-22. doi:10.1056/NEJMcp041025

32. Hueston L, Lanser J, Gidding H, Gilbert L. False positive pertussis tests. Available at http://www.health.nsw.gov.au/ infect/pdf/false_pertussis_tests.pdf [Verified 15 May 2007].

33. Halperin S. The control of pertussis-2007 and beyond. $N$ Engl J Med 2007; 356(2): 110-2. doi:10.1056/NEJMp068288

34. National Health and Medical Research Council. The Australian immunisation handbook. 8th ed. Canberra: Australian Government Department of Health and Ageing, 2003.

35. NSW Health. Policy directive: occupational assessment, screening and vaccination against specified infectious diseases. NSW: NSW Health, 2007.

36. Hethcote HW, Horby P, McIntyre P. Using computer simulations to compare pertussis vaccination strategies in Australia. Vaccine 2004; 22: 2181-91. doi:10.1016/j.vaccine.2003.11.053

37. Forsyth K, Nagai M, Lepetic A, Trindale E. Pertussis immunization in the Global Pertussis Initiative International Region: Recommended strategies and implementation considerations. Pediatr Infect Dis J 2005; 24: S93-7. doi:10.1097/01.inf. 0000160921.74004 .12

38. Scuffman PA, McIntyre PB. Pertussis vaccination strategies for neonates - an exploratory cost-effectiveness analysis. Vaccine 2004; 22: 2953-64. doi:10.1016/j.vaccine.2003.11.057

\section{A Decisive Decade in Immunisation}

The National Centre for Immunisation Research \& Surveillance (NCIRS) is pleased to announce its 10th Anniversary, which will be celebrated with a 1-day conference on Wednesday 18 July 2007 titled 'A Decisive Decade in Immunisation. This will be followed by a dinner.

The conference will be held in conjunction with the 2nd National Immunisation Workshop and will feature prominent international guest speakers including Professor Scott Halperin from the Canadian Center for Vaccinology and Professor Heinz-Josef Schmitt from Johannes Gutenberg University, Germany.

The venue is The Refectory, The University of Sydney. Details regarding these events including programs for both days and registration forms can be found at http://www.ncirs.usyd.edu.au/ or call or email Joanne Perkins (Ph:(02) 9845 1433, Email:joannep3@chw.edu.au) for further information. 


\section{Obituary: Professor Aileen Plant (1948-2007)}

Professor Aileen Plant died in late March 2007 while in Indonesia at a World Health Organization (WHO) meeting on avian influenza. Aileen was the doyenne of communicable disease control in Australia, and through her enthusiasm, good humour and downright common sense inspired many who work in this field, both here and overseas.

Aileen was instrumental in developing many of Australia's training programs and policies for disease control. Among her many roles over the years, some directly affected public health practitioners in NSW, including: working in disease control at NSW Health; teaching in the University of Sydney's Master of Public Health program and collaborating with research up to the time of her death; helping establish the Australian National University's Master of Applied Epidemiology program and being the inaugural Director of that program; and serving as a long-standing member of the Communicable Disease Network of Australia. Aileen also worked extensively on disease control with the WHO, was Professor of International Health at the Curtin University of Technology as well as Deputy Director of the Australian Biosecurity CRC, and held many other positions.

Among her many outstanding achievements, Aileen was among the first in the world to demonstrate that SARS could be controlled. At that time, she took over from the recently deceased Dr Carlo Urbani, who had alerted the world to this new disease and who himself succumbed to it. At great risk from the unknown, Aileen stepped into his shoes in Hanoi and with her team finally managed to contain the outbreak, inspiring others around the world to get on and win the battle.

Aileen trained and mentored many who now work in the NSW public health network. In her teaching and training roles, she was remarkable for her energy, her kindness and for conveying so vividly her real passion for public health. In 2005, she took time out of her busy schedule to teach public health unit staff and trainee public health officers at a communicable disease workshop at the NSW Department of Health. In March 2007, Aileen taught at an Advanced Disease Outbreak Workshop in Newcastle and - only days before her untimely death - she participated in the 2007 Communicable Disease Control conference in Canberra. She attended her last WHO meeting in Jakarta despite feeling unwell before leaving Australia. She paid the ultimate price for her dedication and unwillingness to let down the side.

Aileen made a remarkable personal contribution to public health in Australia and beyond, as well as helping to build the careers of many others. She shaped the landscape of communicable disease control in Australia, and it will be an emptier landscape without her. Her funeral was testament to how much she was respected and loved, packed to standing room only, with tearful people from all over Australia and the world.

\section{Jeremy M. McAnulty, Louisa R. Jorm and}

C. Raina MacIntyre 


\section{Bug Breakfast in the Bulletin: Ross River virus}

\section{Paula J. Spokes ${ }^{\mathrm{A}, \mathrm{C}}$, Stephen L. Doggett ${ }^{\mathrm{B}}$ and Cameron E. Webb ${ }^{\mathrm{B}}$}

ANSW Public Health Officer Training Program, NSW Department of Health

B Department of Medical Entomology, Institute of Clinical Pathology and Medical Research

${ }^{\mathrm{C}}$ Corresponding author. Email:

paula.spokes@doh.health.nsw.gov.au

Ross River virus (RRV) is the most common mosquitoborne disease notified within Australia and is a significant public health issue for NSW. There have been more than 7500 notifications of RRV in NSW over the past 10 years. Peak seasons occurred in 1996-97 (1547 notified cases) and 2005-06 (1268 notified cases), with an average of 683 notifications for the 11 seasons before this. ${ }^{1}$ The November 2006 Bug Breakfast topic focussed on RRV and outlined a joint regional approach to mosquito management called 'Living with Mosquitoes'.

\section{Ross River virus}

RRV causes RRV disease, which is a non-fatal but debilitating illness. Symptoms include myalgia, arthralgia, fatigue, fever, headache, rash (which is present only in approximately $50 \%$ of cases) and arthritis occurring in multiple joints. ${ }^{2}$ Symptoms can present anywhere from 3 to 21 days after being bitten by an infected mosquito. Whilst the disease can vary in severity and duration, lasting anywhere from 3 to 6 months, many people who acquire the virus will be asymptomatic. There is no specific treatment for RRV disease, highlighting the importance of prevention of infection through vector surveillance, management and control and raising awareness in the community.

\section{Vectors}

RRV has been isolated from many species of mosquitoes in varying regions and environments throughout Australia. The most important vector associated with RRV for inland NSW is Culex annulirostris, and Aedes vigilax and Aedes camptorhynchus are the major coastal vectors. Transmitted to humans through the bite of an infected mosquito, RRV is thought to circulate in reservoir marsupial populations such as kangaroos and wallabies, which, if viraemic, can infect mosquitoes taking a blood meal. Once ingested, the virus multiplies in the salivary glands of the mosquito and is subsequently transmitted to other animals or humans when the mosquito feeds.

\section{Ross River virus in NSW}

Although RRV is notified from all areas within NSW, there are concentrated areas of virus activity such as coastal and rural irrigation regions. These areas have consistently high rates of RRV and account for the majority of notifications in NSW. There have also been outbreaks of $\mathrm{RRV}$ occurring in urban areas in close proximity to natural habitats, indicating locally acquired infection., 4 An example of this was noted in the Sutherland shire, Sydney, where an investigation identified a cluster of seven locally acquired cases in $2006 .{ }^{5}$

Rates of RRV notifications have fluctuated within NSW over the past 10 years with significant variation from season to season. Fluctuations in the number of notifications between seasons are generally associated with a combination of environmental, ecological, climatic and societal factors such as:

- mosquito population increases following heavy rainfall, flooding and high tides inundating coastal wetlands

- mosquito longevity associated with rainfall and humidity levels

- climate variability (including temperature and rainfall) influencing seasonal mosquito activity

- regional changes in virus activity

- urban developments around wetlands and coastal regions providing close contact between vertebrate reservoirs, vectors and human populations.

For these reasons a coordinated approach to mosquito management is required and should involve a range of stakeholders, including public health, environment health, local council, state government and interested local agencies.

\section{Mosquito management}

An example of a coordinated response to mosquito populations and arbovirus activity in NSW, is the region-wide approach in the Lower Hunter and Mid-North coast region developed by five local councils and stakeholders and coordinated by the Premier's Department. The mosquito management strategy 'Living with Mosquitoes' was developed as a result of this collaboration with an aim to minimise the impact of mosquitoes and the incidence of mosquito-borne disease by raising awareness of mosquitoes in the local area. ${ }^{6}$

Recommendations of the strategy included:

- the formation of a regional mosquito focus group

- the establishment of coordinated mosquito population monitoring

- targeted mosquito control strategies 
- a regional mosquito awareness program

- the establishment of a mosquito awareness officer position

- the incorporation of mosquito awareness in urban design

- further research into mosquito ecology, arbovirus activity and the role of mosquitoes in the regional ecosystem.

A working group coordinated by the NSW Premier's Department was formed to manage resource allocation and implement the recommendations of the strategy. Members included the five local councils, Hunter New England Health, Department of Environment and Conservation, Department of Primary Industries, Australian Quarantine and Inspection Service, Hunter Central Rivers Catchment Management Authority and medical entomologists within the department of Medical Entomology at Westmead Hospital.

'Living with Mosquitoes' was officially launched in 2006. It marks an important step towards a coordinated regional approach to mosquitoes and mosquito-borne disease management in NSW.

\section{References}

1. Health NSW. Notifiable Disease Database. Sydney: NSW Health, 2006.

2. Tong S. Ross River virus disease in Australia: epidemiology, sociology and public health response. Intern Med J 2004; 34 : 58-60. doi:10.1111/j.1444-0903.2004.00520.x

3. Amin J, Hueston L, Dwyer D, Capon A. Ross River virus infection in the north-west outskirts of the Sydney basin. Commun Dis Intell 1998; 22(6): 101-2.

4. Brokenshire T, Symonds D, Reynolds R, Doggett S, Geary M, Russell R. A cluster of locally-acquired Ross River virus infection in outer-western Sydney. NSW Public Health Bull 2000; 11(7): 132-4.

5. Ross River Virus: South Eastern Sydney cluster report. South Eastern Sydney and Illawarra Area Health Service: Randwick Public Health Unit investigation. June 2006.

6. Webb CE, Russell RC. Living with mosquitoes in the Lower Hunter and Mid-North coast region of NSW. Department of Medical Entomology, Institute of Clinical Pathology and Medical Research, Westmead Hospital, 2005. Available at http://www1.hnehealth.nsw.gov.au/hneph/ LivingWithMosquitoes.htm [Verified 16 April 2007]. 


\section{Legionnaires' disease}

\section{What is Legionnaires' disease?}

Legionnaires' disease is an infection of the lungs (pneumonia) caused by bacteria of the Legionella family. There are approximately 70 cases of Legionnaires' disease notified in NSW each year, most of which are caused by Legionella pneumophila. Legionella pneumophila is usually found in warm water, whereas Legionella longbeachae, another bacterium of the Legionella family, is commonly found in soil and potting mix.

\section{What are the symptoms?}

Legionnaires' disease usually causes:

- fever

- chills

- a cough

- shortness of breath

- muscle aches

- headache

- tiredness

- loss of appetite, and

- diarrhoea.

Most people recover from the illness; however, some become very sick with pneumonia and may die.

\section{How is it spread?}

Legionnaires' disease can occur after people have breathed in aerosols from water sources that are contaminated with Legionella pneumophila, for example, from air conditioning cooling towers, whirlpool spas, warm water systems or showers. Sometimes it can occur after breathing aerosols contaminated with Legionella longbeachae from soil, potting mix or dripping water from hanging pot plants. People may be exposed at home, work or in public places.

It is not spread from person to person. The time between the patient's exposure to the bacteria and becoming sick is between 2 and 10 days.

\section{Who is at risk?}

Legionnaires' disease most often affects middle-aged and older people, particularly those who smoke or who have chronic lung disease. People whose immune systems are suppressed by medications or diseases such as cancer, kidney failure, diabetes or HIV infection, are also at increased risk.

\section{How is it prevented?}

Legionella pneumophila bacteria can be found in many types of water systems; however, the bacteria reproduce to high numbers in warm, stagnant water. Good design, disinfection and maintenance of cooling towers and plumbing systems limit the growth and spread of Legionella bacteria. Building occupiers and owners should follow the 'NSW Code of Practice for the Control of Legionnaires Disease. 2nd Edn. 2004' (http://www.health.nsw.gov.au/ pubs/2004/pdf/legionnaires_disease.pdf).

Legionella longbeachae is common in the soil. Reducing exposure to potting mix dust (by following the manufacturers' warning on potting mix labels), wearing gloves and a mask when using potting mix and avoiding breathing in droplets of water from dripping pot plants and when watering plants may help prevent infection. Wash your hands after handling potting mix or soil, especially before eating, drinking, smoking or putting your hand in your mouth.

\section{How is it diagnosed?}

It is difficult to distinguish Legionnaires' disease from other types of pneumonia by symptoms alone. Chest X-rays often show pneumonia but the diagnosis requires special tests. Tests of blood (taken 3 to 6 weeks apart), sputum and urine samples can help to confirm the diagnosis.

\section{How is it treated?}

Legionnaires' disease can be treated with antibiotics. Patients with Legionnaires' disease may be treated in hospital with antibiotics through a drip. Some people may need intensive care and a ventilator to assist them to breathe.

\section{What is the public health response?}

Hospital staff and laboratories must notify cases of Legionnaires' disease to the local public health unit. Public health unit staff will talk with the treating doctor and patient (or their carer) to identify risk factors for the disease. When two cases share a common exposure, the public health unit will work with local council to investigate and control possible sources of infection.

\section{NSW:HEALTH}




\section{Communicable Diseases Report, NSW, January and February 2007}

\section{Communicable Diseases Branch, NSW Department of Health}

For updated information, including data and facts on specific diseases, visit www.health.nsw.gov.au and click on Infectious Diseases.

Tables 1 and 2 and Fig. 1 show reports of communicable diseases received through to the end of January and February 2007 in NSW.

\section{Legionnaires' disease - Circular Quay}

In January 2007, 10 cases of legionellosis due to Legionella pneumophila (serogroup 1) were notified to NSW Health. Six of these cases (five men and one woman, aged between 46 and 64 years) had visited Circular Quay on 31 December 2006, which was within the incubation period. A seventh case, a traveller who had also visited Circular Quay on 31 December, was diagnosed in the United Kingdom and was notified to NSW Health through the European Working Group for Legionella Infections.

NSW Health initiated an investigation into the cause of the outbreak. Active case finding was initiated: public health units solicited reports of additional suspected cases from local emergency departments, respiratory physicians and intensive care units and information about the cluster was faxed to NSW general practitioners and respiratory physicians. Substantial media coverage prompted several patients to present to medical practitioners and the diagnosis was confirmed in one of these.

Environmental health officers from South Eastern Sydney/Illawarra Public Health Unit and the City of Sydney Council initiated an environmental investigation of potential sources of contaminated aerosols in the Circular Quay area, such as cooling towers. Twenty-five cooling towers in the area were evaluated for compliance with Public Health (Microbial Control) Regulation 2000. ${ }^{1}$ One of these, an inadequately maintained cooling tower in a building at the east end of Circular Quay, returned a high Legionella count (1400 colony forming units per $\mathrm{mL}$ ). The cooling tower was immediately shut down, cleaned and decontaminated. It is uncertain whether or not this cooling tower was the source of the cases.

This cluster highlights the importance of registration and maintenance of cooling towers, especially in places where many people may be exposed.

\section{Mumps in North Coast Area Health Service}

NSW Health was notified of five cases of mumps from among children aged 10-16 years old who attended the 'South Pacific Pathfinder Camporee', a church-based event held on the Mid North Coast of NSW in January 2007. Approximately 2900 of 6700 participants in the event were visitors from overseas. All five cases were in children from the Pacific Islands (two cases were from the Solomon Islands, two from Vanuatu and one case was from Fiji).

The cases appear to have been infected in their homelands before travelling to Australia and were otherwise unrelated. Unlike Australia, a mumps-containing vaccine is not included in the standard immunisation schedule of these countries. $^{2}$

With each clinical diagnosis of mumps, event officials rapidly isolated each case. The North Coast Public Health Unit initiated active case finding for the duration of the camp, and written information about mumps and measles-mumps-rubella (MMR) vaccination was given to all camp participants. MMR immunisation was not feasible because informed consent could not be readily obtained for children from overseas and contraindications to immunisation could not be reliably identified.

The large majority of Australian and New Zealand children at the camp were expected to be immune through previous immunisation with MMR. No information about immunisation status was collected from any of the participants at registration.

Subsequently no secondary cases were reported in NSW.

\section{Norovirus outbreak in a tour group}

South Eastern Sydney/Illawarra Public Health Unit investigated an outbreak of gastroenteritis among a group of Japanese school students who visited Sydney from 27 to 30 January 2007. Fifty-eight of the 237 students were reported unwell with vomiting and/or diarrhoea. 
By the time the hotel doctor reported the outbreak, most of the students were on their way back to Japan, but several had delayed their return as they were too unwell to travel. Public health unit investigators interviewed the tour organisers and the hotel doctor about illness in the students, the nature of the tour and meals consumed, and arranged for stools from the students to be tested for a range of pathogens.

Of the 237 students, the ill students were among a subset of 116 who visited a farm and other locations (where meals were consumed) over a 2-day period. The high attack rate, nature of the symptoms and close clustering in time of the onset of illness suggested that the outbreak was likely due to norovirus infection acquired at a single event (i.e. a point-source outbreak), most likely during the consumption of a common meal.

Norovirus was detected in stools from one student in Australia, and reported from one ill student tested in Japan. As norovirus has an incubation period of 24 to 48 hours, the investigation focused on the exposures that the ill students had had during that period before onset of illness.

The NSW Food Authority inspected the restaurant and the farm where the students ate and stayed during the incubation period. No ill food handlers were identified and no likely source of contamination was identified at either facility.

Norovirus is a common cause of vomiting and diarrhoea, particularly in the winter months. Norovirus is highly infectious and spreads easily from person to person through contact with faeces or vomitus, or through contact with surfaces that have the virus on them.

While the source of this outbreak remains unconfirmed, a likely explanation appears to be contamination of a shared meal by a food handler or a patron. Sick food handlers should stay away from work for 48 hours after their diarrhoea has stopped, and ready-to-eat food should be presented in a way that protects it from contamination by consumers.

\section{Histamine (scombroid) fish poisoning}

In February 2007, NSW Health was notified of two outbreaks of histamine fish poisoning. In the first outbreak, Western Sydney Public Health Unit (Parramatta Office) was notified by an emergency department doctor of three cases who had eaten home-cooked tuna kebabs. The cases had developed facial flushing, a burning sensation of the face and mouth, increased heart rate, headache and rash within 45 min of eating the kebabs. On the same day, Western Sydney Public Health Unit (Penrith Office) was notified of a second outbreak involving two patients, who presented to hospital after eating tuna in a restaurant in the Blue Mountains. All cases recovered.

In a trace-back investigation, the NSW Food Authority found that the tuna in both outbreaks had been caught wild in Indonesia and separately imported into Queensland. Further investigation is underway.

Histamine fish poisoning is among the more common causes of illness linked to fish consumption. It is usually associated with eating fish from the scombroid family, such as tuna and mackerel, but can be caused by other fish. ${ }^{3}$ Histamine is produced in the fish during bacterial decomposition, following its capture. The formation of histamines can be prevented by gutting the fish, removing the gills and rapid refrigeration throughout the supply chain. ${ }^{4}$

\section{False positive pertussis serological tests}

\section{Linda Hueston $^{\mathrm{A}, \mathrm{B}, \mathrm{C}}$, Jan Lanser ${ }^{\mathrm{A}, \mathrm{B}}$, Heather Gidding ${ }^{\mathrm{A}, \mathrm{B}}$ and Lyn Gilbert ${ }^{\mathrm{A}, \mathrm{B}}$

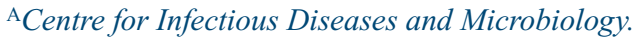 \\ ${ }^{\mathrm{B}}$ Institute of Clinical Pathology and Medical Research. \\ ${ }^{\mathrm{C}}$ Corresponding author.Email: lindah@icpmr.wsahs.nsw.gov.au}

Following substantial increases in pertussis notifications in Australia based on positive serological tests (but not other diagnostic criteria) in 2005 and 2006, concerns were raised by laboratory-based serologists about the accuracy of serology as a diagnostic criterion for pertussis.

In September 2006, PanBio (whose pertussis whole cell IgA antibody test is used by more than $80 \%$ of Australian laboratories), in consultation with the Therapeutic Goods Administration, issued a 'recall for product correction' for three batches of its pertussis IgA serology kit. This kit had been used over the previous 12 months in Australia. A new 'cut-off' for reporting a positive result, 2.5 times higher than previously recommended, was issued for the kits until a new version could be released.

The Centre for Infectious Diseases and Microbiology (CIDM) recalculated all PanBio pertussis IgA enzyme immunoassay results obtained between 25 January and 9 October 2006 using the new cut-off. Of the 1547 samples tested for pertussis IgA with the original cut-off, 405 had been notified as positive and 171 equivocal. With the new cut-off, only 64 (16\% of the original number that were positive) would have been positive and 40 equivocal.

In response to these results, CIDM compared the new and old PanBio kits and several other commercial kits. Panels of positive and negative sera were chosen on the basis of clinical criteria and positive or negative results from a combination of three serological assays used as 'gold 
standard'- complement fixation, immunofluorescence and a commercial Western blot.

The evaluation showed that:

- Approximately $75 \%$ of samples that were positive with the old PanBio kit in 2006 were negative when tested with 'gold standard' methods. The majority of falsepositive results were due to non-specific crossreactions with the filamentous haemagglutinin as demonstrated by Western blot. Although crossreactions with filamentous haemagglutinin antigen are known to occur in some other respiratory illnesses, including influenza and mycoplasma infection, all negative sera used in this evaluation were from healthy adults without a cough.

- Neither of the two commercial kits used by laboratories in NSW in 2006 performed well when compared with the gold standard tests and some of the other commercially available kits.

- Three commercial kits performed significantly better than all others, based on a combination of specificity (98-99\%) and sensitivity (74-78\%) and will be further tested in a prospective study.

- The Western blot kit (MarDx Bordetella pertussis IgA Marblot test) is a useful confirmatory test.

Since the recall of the testing kit in September 2006, the number of pertussis notifications in NSW has fallen from more than 700 cases per month to less than 300 (see: http:/www.health.nsw.gov.au/data/diseases/pertussis.html, verified 27 April 2007). Pertussis is classically a clinical diagnosis, based on symptoms of a persistent paroxysmal cough, which in children is typically followed by an inspiratory whoop, and vomiting. Diagnosis can be confirmed by culture, polymerase chain reaction testing or serology, the results of which must be interpreted in light of clinical features of the case.

Note: Use of trade names does not imply endorsement by NSW Health.

\section{References}

1. NSW Public Health Act 1991 and Public Health (Microbial Control) Regulation 2000 (amended July 2003) Available at http://www.health.nsw.gov.au/public-health/ehb/general/ microbial/microbial.html [Verified 27 April 2007].

2. WHO Vaccine Preventable Diseases Monitoring System. Immunization schedules by antigen, selection centre (updated 22 December 2006) Available at http://www.who.int/ immunization_monitoring/en/globalsummary/ ScheduleSelect.cfm [Verified 27 April 2007].

3. Hocking AD, editor. Foodborne microorganisms of public health significance. 6th edn. Waterloo: AIFST Inc. Food Microbiology Group, 2003.

4. Heymann DL, editor. Control of communicable disease manual. 18th edn. Washington, DC: American Public Health Association, 2004. pp. 217-218. 
Fig 1. Reports of selected communicable diseases, NSW, January 2002 to February 2007, by month of onset. Preliminary data: case counts in recent months may increase because of reporting delays. Laboratoryconfirmed cases only, except for measles, meningococcal disease and pertussis.

$\mathrm{BFV}=$ Barmah Forest virus infections, RRV = Ross River virus infections. Lab Conf $=$ laboratory confirmed.

Men $\mathrm{Gp} C$ and $\mathrm{Gp} \mathrm{B}=$ meningococcal disease due to serogroup $\mathrm{C}$ and serogroup $\mathrm{B}$ infection, other/unk = other or unknown serogroups. NB: multiple series in graphs are stacked, except gastroenteritis outbreaks.

NB: Outbreaks are more likely to be reported by nursing homes and hospitals than by other institutions.

\begin{tabular}{|lc|}
\hline \multicolumn{2}{|c|}{ NSW Population } \\
Male & $50 \%$ \\
$<5$ y & $7 \%$ \\
$5-24$ y & $27 \%$ \\
$25-64$ y & $53 \%$ \\
$65+$ y & $13 \%$ \\
Rural & $46 \%$ \\
\hline
\end{tabular}
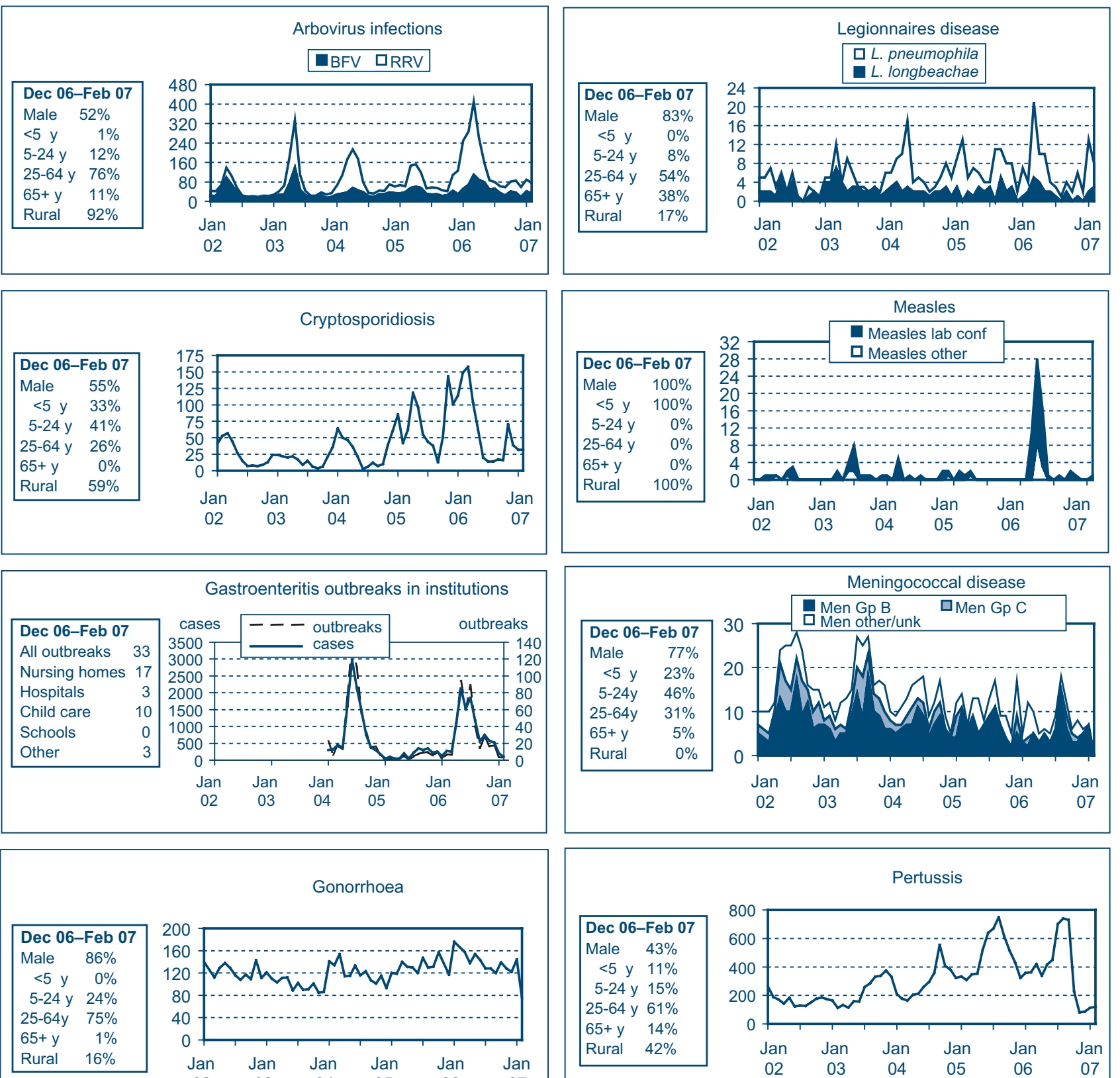

Gonorrhoea

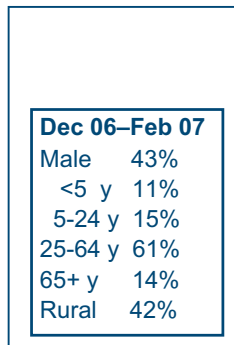

Pertussis
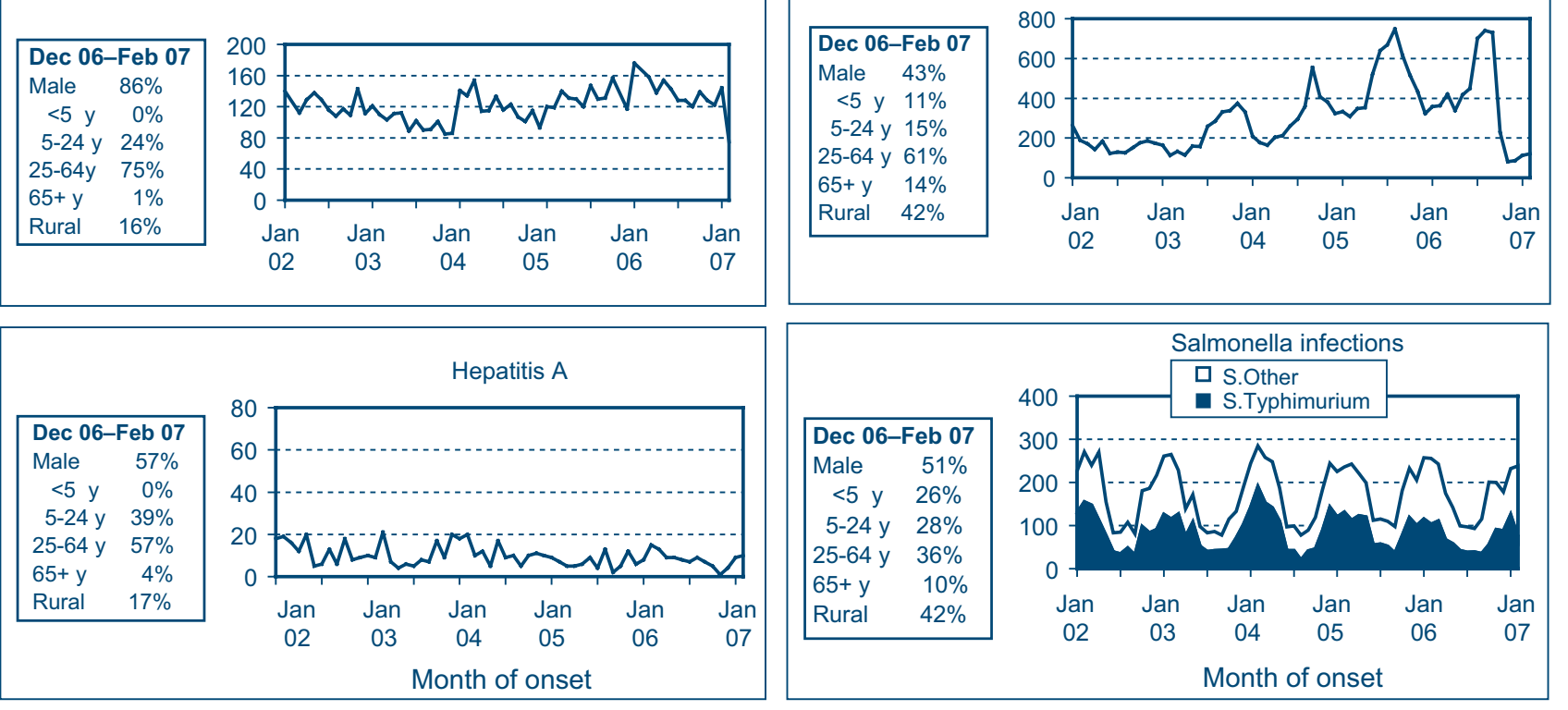
Table 1. Reports of notifiable conditions received in January 2007 by Area Health Services

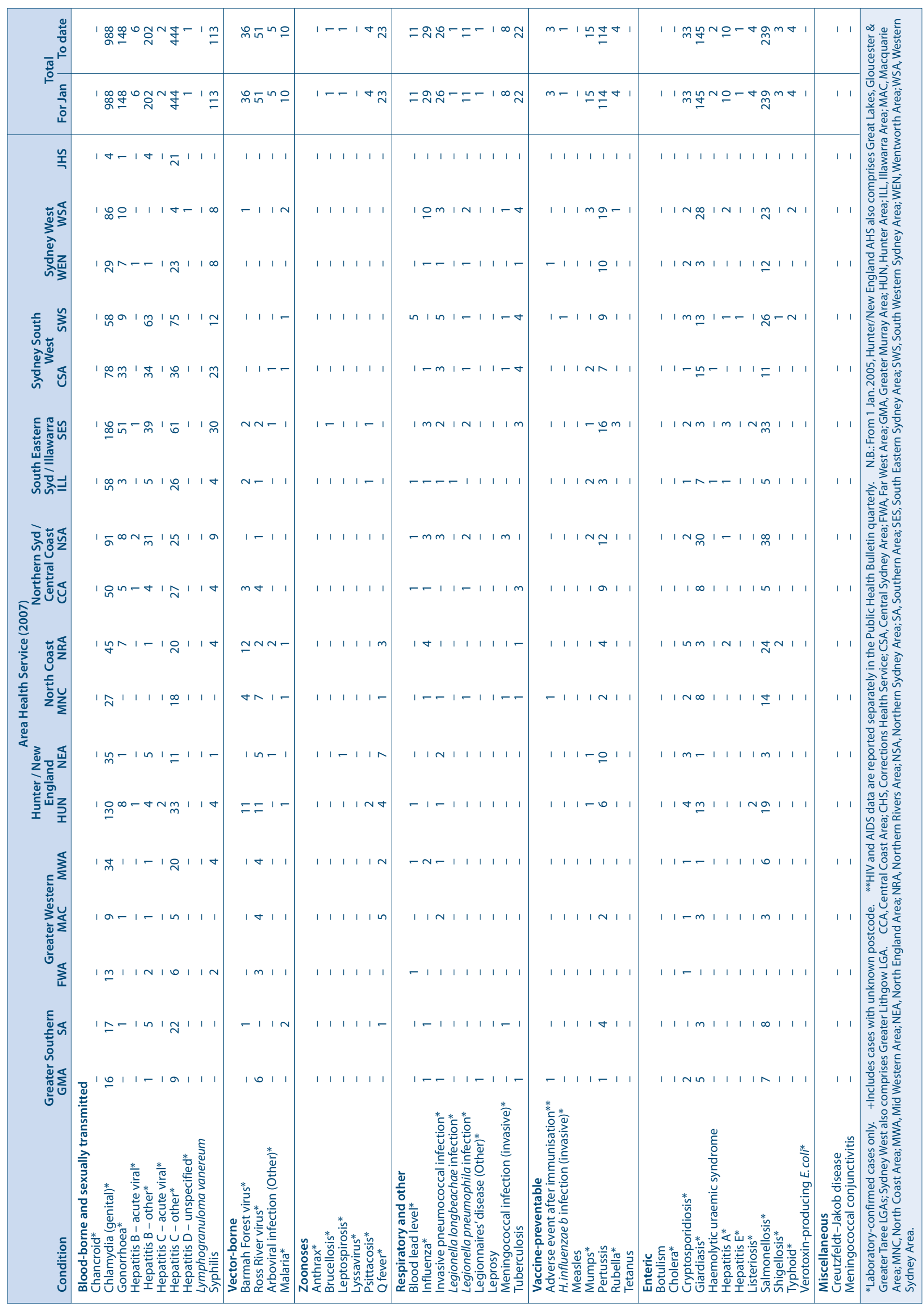


Table 2. Reports of notifiable conditions received in February 2007 by Area Health Services

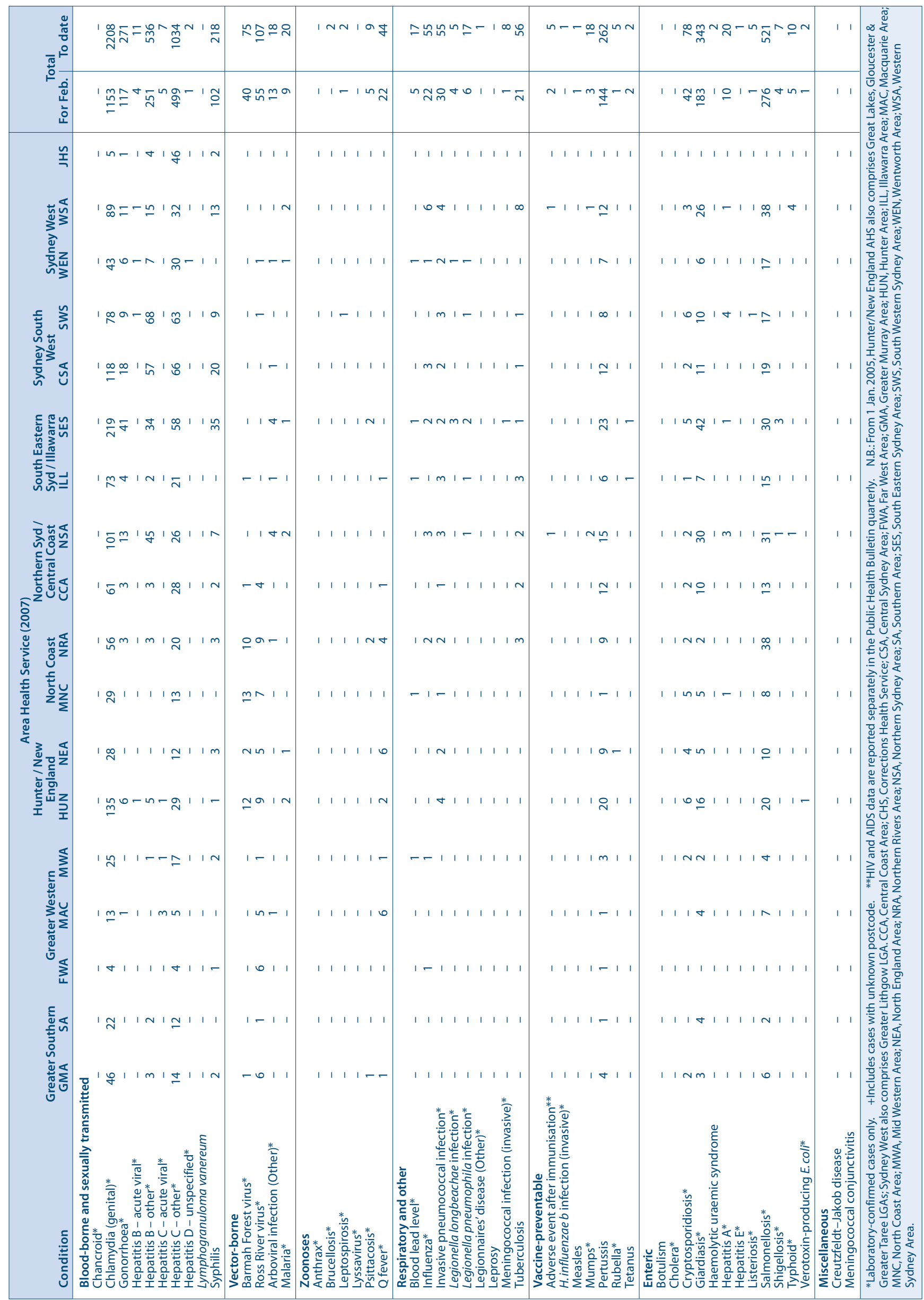




\section{Contents}

\section{Special issue: Cities, sustainability and health}

37 Creating healthy, just and eco-sensitive cities This editorial introduces this, the first of two, special issues that examine health and cities.

Anthony G. Capon and Jane M. Dixon

40 Report on the health impact assessment of the Sydney Metropolitan Strategy in greater western Sydney Provides a short description of the health impact assessment; the final report will be released in mid-2007.

41 Will considerations of environmental sustainability revitalise the policy links between the urban environment and health?

Describes past (infectious diseases and pollution) and present (obesity and climate change) health hazards associated with cities.

Anthony J. McMichael

45 Developing a national approach to building healthy and sustainable cities

Introduces initiatives for improving urban governance to enable the implementation of a healthy and sustainable cities agenda.

Renate Howe

48 A social-ecological perspective on health in urban environments

An integrative urban science agenda is needed to inform urban policy, planning and design, and to educate people. Allen Kearns, Matthew Beaty and Guy Barnett
51 Checklist for healthy and sustainable communities The 10-point checklist is offered as a tool for those who plan, develop and manage urban environments. Anthony G. Capon and Edward J. Blakely

55 EPIREVIEW. Pertussis in NSW, 1993-2005: the impact of vaccination policy on pertussis epidemiology The highest rates of pertussis were in infants aged 0-6 months, however rates of disease in other age-groups changed markedly over the study period.

Kerri A. Viney, Jeremy M. McAnulty and Sue Campbell-Lloyd

62 Obituary: Professor Aileen Plant (1948-2007)

Jeremy M. McAnulty, Louisa R. Jorm and C. Raina Maclntyre

\section{Bug Breakfast in the Bulletin}

63 Ross River virus

Paula J. Spokes, Stephen L. Doggett and Cameron E. Webb

\section{Factsheet}

65 Legionnaires' Disease

\section{Communicable Diseases Report, New South Wales}

66 January-February 2007

\section{NSW PUBLIC HEALTH BULLETIN}

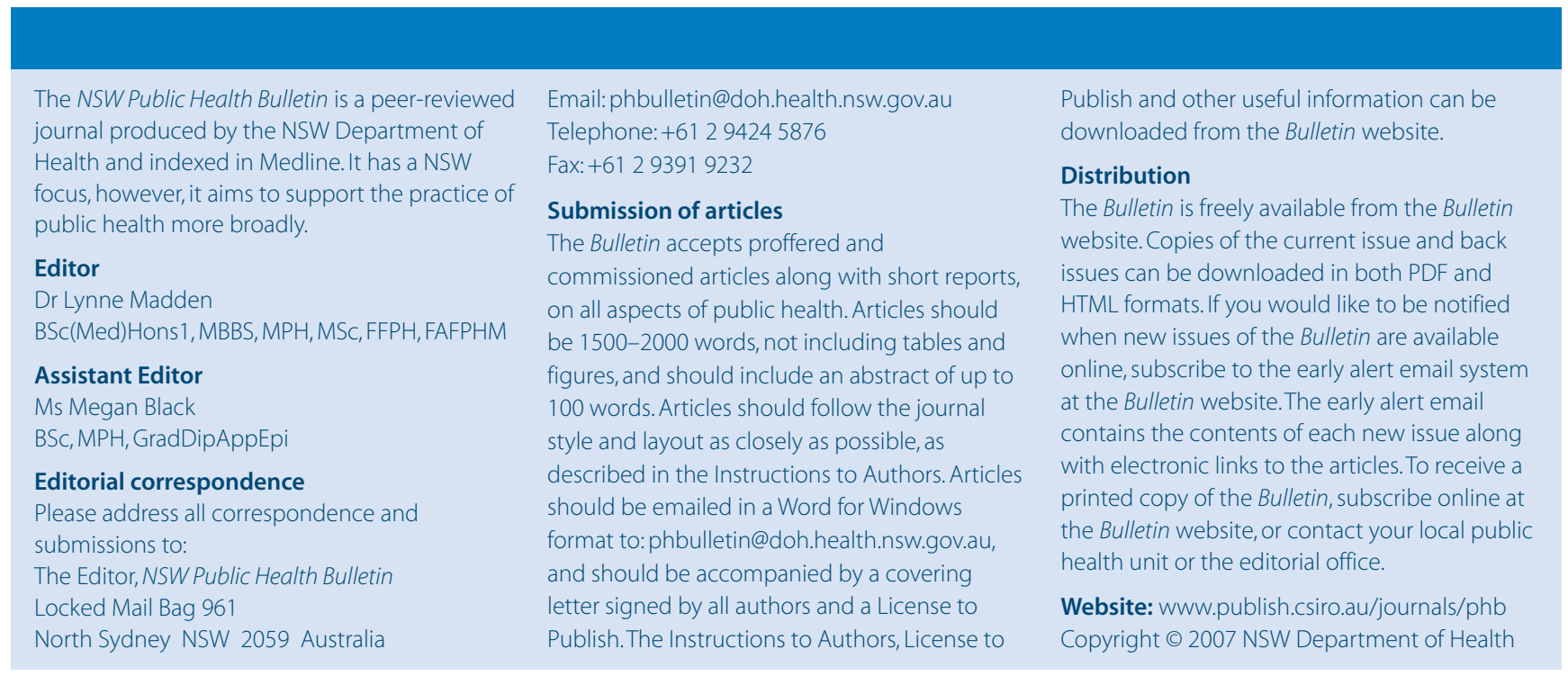

